\title{
DOKUMENTÁCIA TERÉNNYCH RELIKTOV OPEVNENÝCH SÍDIEL V KOSTOLIANSKEJ KOTLINE A JEJ ŠIRŠOM OKOLÍ POMOCOU MODERNÝCH METÓD ${ }^{1}$
}

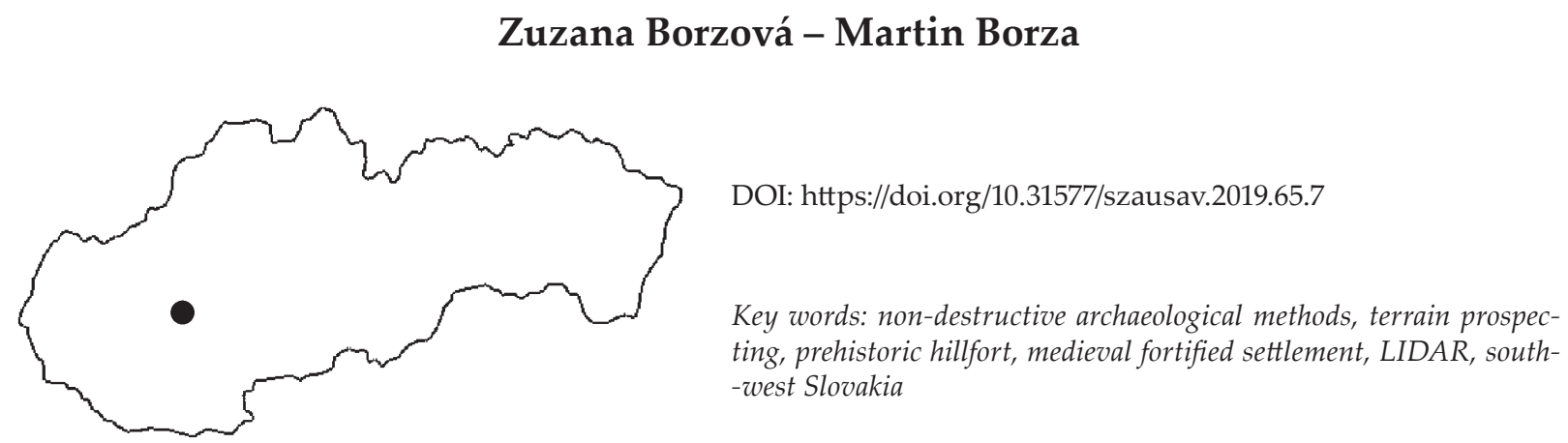

Documentation of Terrain Relics of Fortified Settlements in the Kostolianska kotlina Basin and its Wider Surroundings by Means of Modern Methods

The topic of this article is presentation of use of the latest (non-destructive) methods at identification, recording and detailed documentation of selected terrain relics of historical fortified settlements in the Kostolianska kotlina basin and its surroundings. Comparing new knowledge obtained by means of modern methods with results of our own terrain prospecting and currently known (previously published) information outside our investigation, a new picture of individual relics is created. We deal with the prehistoric hillfort of Vel'ký Tribeč and relics of medieval fortified settlements - a medieval hillfort in Velčice and a medieval fortified settlement of Studený hrad.

\section{ÚVOD}

Skúmaný mikroregión sa rozprestiera v oblasti juhovýchodných výbežkov pohoria Tribeč, približne 16 km severovýchodne od Nitry a $11 \mathrm{~km}$ severozápadne od Zlatých Moraviec. Celé záujmové územie predstavuje 95,12 km² skúmanej plochy, z čoho centrálnu a zároveň najväčšiu čast’ tvorí Kostolianska kotlina. Okrem nej zahŕňa aj prilahlé výšinné polohy a ich úbočia. Na severe je mikroregión ohraničený chrbtom pohoria, ktorého najvyšší vrch v tejto časti je Vel'ký Tribeč $(829,6 \mathrm{~m} \mathrm{n}$. m.). Na západe okrem prilahlého vrchu Dúň (514 m n. m.) patrí celé údolie Jelenského potoka až po vrch Plieška (374,5 m n. m.), na juhozápade Stará skala (376 m n. m.) a Čierna skala (454,6 m n. m.) na západe. Na východe je Kostolianska kotlina ohraničená vrchmi Ploská (577 m n. m.), Vel'ký Lysec (547 m n. m.) a Malý Lysec (492 m n. m.), avšak skúmaná oblast̉ dalej pokračuje po údolie Čerešňového potoka. V južnej časti sa otvára do Žitavskej pahorkatiny (Borzová 2017, 8, obr. 2).

Záujmová oblast', vd’aka svojmu georeliéfu, vhodným klimatickým podmienkam, bohatým ložiskám kamennej suroviny a dreva, bola s rôznou intenzitou osídlená nepretržite, od praveku podnes (Bisták/ Borzová 2013; Borzová 2013, 21-30; Borzová/Čurný/Pažinová 2010; Borzová/Pažinová 2009; Ruttkayová/Ruttkay 1991). Z hladiska priestorového rozmiestnenia archeologických lokalít je charakteristická vel'kým výskytom terénnych reliktov antropogénneho charakteru z rôznych pravekých aj historických období v zalesnenej časti skúmaného mikroregiónu. Za najstaršie možno považovat’ dve hradiská lužickej kultúry: na temene vrchu Vel'ký Tribeč a temene a svahoch Vel'kého a Malého Lysca. Zo stredoveku ide o hrad Gýmeš - najvýznamnejšie historické opevnené sídlo v skúmanom mikroregióne a rezidenčné sídla v podobe menšieho stredovekého opevnenia v polohe Studený hrad a stredovekého hrádku vo Velčiciach. Okrem zmienených opevnených sídiel sú v sledovanom mikroregióne identifikované aj iné terénne relikty antropogénneho charakteru zo stredoveku a novoveku a to s hospodárskym využitím.

1 Práca vznikla v rámci projektu 2/0037/17 agentúry VEGA „Úloha materiálnej kultúry pri formovaní ekonomických, sociálnych a interetnických väzieb v stredovekých komunitách“ a projektu 2/0018/19 SAV „Ekologické analýzy akulturácie krajiny Slovenska od mladšieho praveku dodnes“. Niektoré jeho časti sú súčastou nepublikovanej habilitačnej práce spoluautorky Z. Borzovej (2017). 


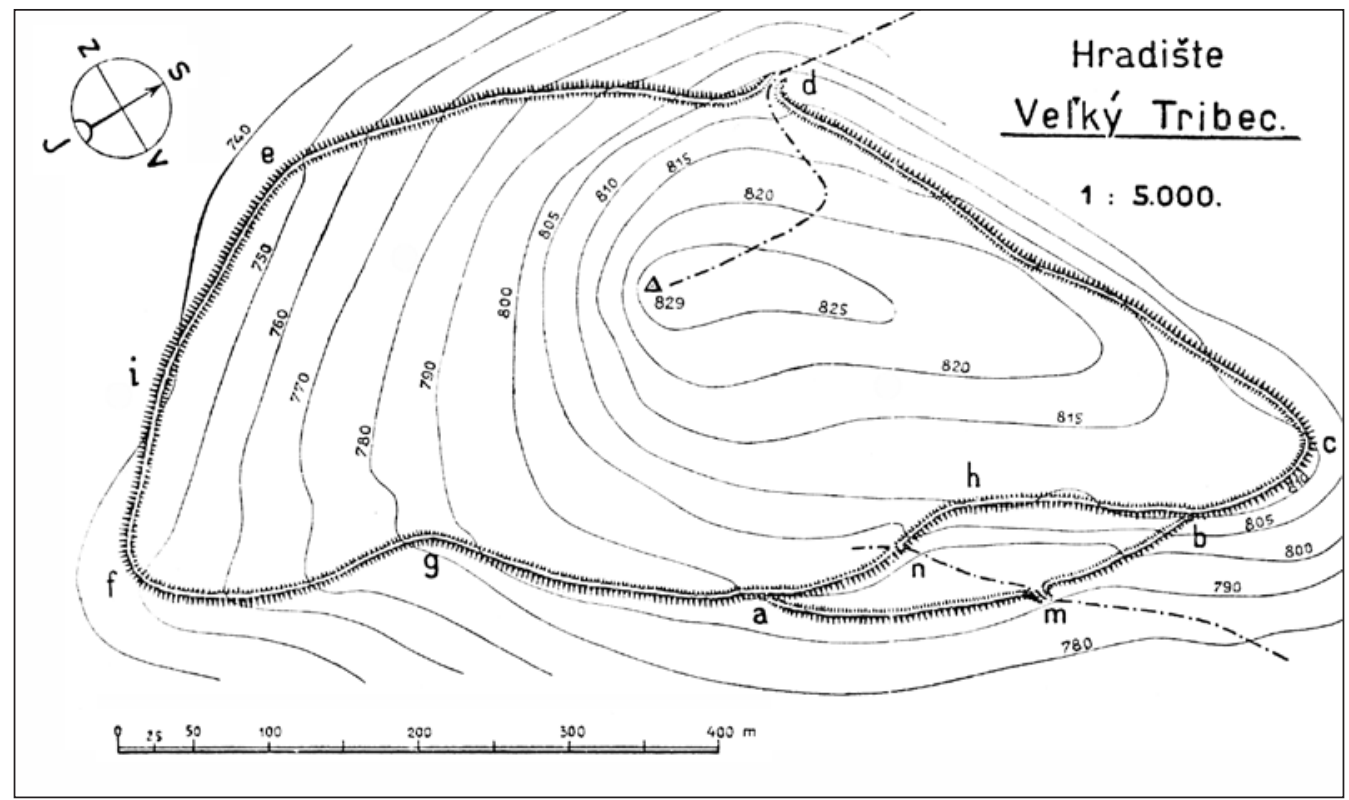

Obr. 1. Vel'ký Tribeč. Plán hradiska z roku 1929 (podl’a Janšák 1929, obr. 24).

Ide o viaceré relikty tažobných areálov (lomy, kameňolomy, tažobné jamy) a výrobných objektov (vápenky, mlyny, sklárska huta a bližšie neurčené pece; Bisták/Borzová 2018; Borzová 2017, 162-183; Borzová et al. 2017; Borzová/Borza/Bisták 2014, 39-43; Jahn 1997; 2009; Samuel/Jahn/Hunka 2003). S osídlením Kostolianskej kotliny a jej širšieho okolia nepochybne súvisia aj d’alšie relikty, historické komunikácie a relikty starých ciest (Borzová 2017, 42, 43).

Výskum vyššie zmienených terénnych reliktov si okrem interdisciplinárnej spolupráce a využitia výsledkov z ostatných vedných disciplín vyžaduje aj aplikáciu viacerých archeologických metód a následnú komparáciu získaných výsledkov. Prostredníctvom tohto príspevku chceme poukázat nielen na túto skutočnost', ale predovšetkým na možnosti využitia nových (nedeštruktívnych) metód pri identifikácii, dokumentácii a evidencii, ako aj d’alšom výskume vybraných terénnych reliktov historických opevnených sídiel v Kostolianskej kotline a jej okolí. Ide o praveké hradisko Vel'ký Tribeč a relikty stredovekých opevnených sídiel: hrádok vo Velčiciach a opevnené sídlo Studený hrad. ${ }^{2}$

\section{METÓDY VÝSKUMU VYBRANÝCH RELIKTOV}

Prvotný súbor dát, ako aj primárny obraz o skúmaných lokalitách, sa podarilo získał sumarizáciou doposial známych výsledkov, t. j. z predchádzajúcich výskumov. ${ }^{3}$

Samotný (archeologický) výskum pozostával predovšetkým z terénnej prospekcie, resp. z povrchového prieskumu reliéfnych tvarov vybraných historických opevnení, väčšinou v spolupráci archeológov s geológom, geomorfologičkou a geodetom (Borzová 2017, 28-53; obr. 40). Povrchové prieskumy (uskutočnené s ciel'om vyhladávania a mapovania doposial neznámych objektov, ako aj so zámerom získavania nových informácií o už známych objektoch) boli realizované v rokoch 2004-2006 ${ }^{4}$, predovšetkým však od roku 2008 až dodnes v rámci riešenia viacerých projektov. ${ }^{5}$

2 Praveké hradisko so zázemím na temene a svahoch Vel'kého a Malého Lysca bolo týmto spôsobom spracované a publikované v roku 2017 (Bisták/Borzová/Borza 2017). Tak isto ani stredoveký hrad Gýmeš nie je v tomto príspevku spracovaný, nakol'ko nami využité metódy nie sú najvhodnejšie pre spracovanie lokalít s nadzemnou ruinálnou architektúrou, akým je aj zmienený hrad.

3 K histórii bádania a stavu poznania Kostolianskej kotliny a jej okolia pozri napr. Borzová/Borza/Bisták 2014, 19-21.

4 V réžii Pamiatkového úradu SR a Krajského pamiatkového úradu v Nitre.

5 Predovšetkým v rámci riešenia medzinárodného projektu „Cradles of European Culture - Francia Media 850-1050“, ako aj projektu VEGA a SAV 1/0208/15 „Človek a hory v priebehu času - od pravekých hradísk k stredovekým hradom“ a projektu UGA I-12-208-01 „Multidisciplinárny prieskum krajiny. Projekt - Kostolianska dolina. 
Metódou dial'kového prieskumu krajiny leteckým laserovým skenovaním (LLS), ktoré sa uskutočnilo v roku 2015, bol vytvorený digitálny model reliéfu (DMR; Bisták/Borzová/Borza 2017, 50). Na tieňovaných reliéfoch DMR bolo možné sledovat’ a bližšie skúmat’ zmienené relikty opevnení. ${ }^{6}$

Na zjednodušenie automatickej identifikácie a analýzy štrukturálnych prvkov DMR súvisiacich so zmienenými archeologickými lokalitami bola použitá morfometrická analýza terénu pomocou inovatívnej metódy s využitím technológie Proxima. ${ }^{7}$ Hlavným výstupom analýzy je konvexná a konkávna charakteristika analyzovaného terénu. Výsledky analýzy sú generované vo viacerých úrovniach detailu, ktoré zaistujú identifikáciu a vizualizáciu detailných objektov s vlastnostami na viacerých mierkových úrovniach (Holubec et al. 2016). Táto metóda ponúka iný pohlad na terén. Na rozdiel od globálneho vizuálneho vyhodnocovania DMR jeho osvetlením z rôznych smerov, pri tejto analýze vidíme lokálne vypukliny (konvexity) a vydutiny (konkavity) terénu bez ohladu na smer pozorovania.

Získané výstupy z LLS (tieňované reliéfy a morfometrická analýza) ${ }^{8}$ boli porovnané s výsledkami nášho terénneho výskumu a s výsledkami predchádzajúcich výskumov. Pomocou tejto metódy sa doteraz podarilo detailnejšie vyhodnotit terénne relikty hradiska na Vel'kom a Malom Lysci (Bisták/Borzovál Borza 2017), ako aj relikty hospodárskeho využitia v oblasti masívu Vel'kého Lysca a Ploskej (Borzová et al. 2017).

\section{TERÉNNE RELIKTY OPEVNENÝCH SÍDIEL - DOKUMENTÁCIA A NEDEŠTRUKTÍVNY VÝSKUM MODERNÝMI METÓDAMI}

\section{Vel'ký Tribeč - hradisko lužickej kultúry}

V najsevernejšej časti skúmaného územia, na rozhraní katastrov Kovarce a Velčice, na temene vrchu Vel'ký Tribeč s kótou 829,6 m n. m., sa rozprestiera mohutné hradisko.

V odbornej spisbe sa prvýkrát objavuje už v roku 1929, kedy ho spomína Š. Janšák $(1929,16,17) .{ }^{9}$ Povrchovým zberom a prospekciou boli v priestore hradiska nájdené zlomky keramiky prevažne lužickej kultúry počas viacerých sezón prieskumov v rokoch 1956, 1967, 1989, 2001, 2004, 2008 (Borzová 2017, 137; Katkinová/Katkin 2002; Mitáš/Žáčik 2011; Ruttkayová/Ruttkay 1991, 45). Prostredníctvom prospekcie a obhliadok boli zdokumentované aj terénne relikty hradiska. Okrem nich sa začiatkom 21. stor. uskutočnilo viacnásobné letecké snímkovanie a meranie GPS. Výstupy LLS v podobe tieňovaného reliéfu, ako aj letecké snímky, sú publikované v roku 2015 (Ruttkay 2015, 323, 324, obr. 33; 34). Pôdorys hradiska v minulosti zameral Š. Janšák (obr. 1).

Hradisko s rozlohou vnútornej plochy 15,6 ha ${ }^{10}$ je opevnené valom prerušeným na niekolkých miestach. V severozápadnej časti hradiska ho prerušuje brána, ktorú prvýkrát identifikoval Š. Janšák (1929, obr. 24d) a interpretoval ako bránu s von vybiehajúcimi valmi. Neskôr ju špecifikoval L. Veliačik a P. Romsauer (1994, 87) ako poloklieštovú bránu, žial', bez obrazovej prílohy. Najnovší výstup v podobe tieňovaného reliéfu bol publikovaný M. Ruttkayom (2015, 324, obr. 34), ktorý zmienenú bránu interpretuje ako klieštovú. Na základe najnovších poznatkov pomocou LLS a technológie Proxima možno detailne sledovat zmienenú bránu, najlepšie na výstupe morfometrickej analýzy konvexít. ${ }^{11}$ Konvexity viditel’ne vykreslujú tvar brány s dovnútra vtiahnutým spodným valom, vytvárajúcim tak typický tvar poloklieštovej brány ${ }^{12}$ (obr. $\left.2 ; 3 a ; 4\right)$.

6 Niektoré z nich sú známe už zo skoršej odbornej spisby, napr. Ruttkay 2015, 322-325, obr. 32-35; Ruttkayová/Ruttkay 2015.

7 Princípom je kvantitatívna charakteristika digitálneho povrchu pomocou teórie diferenciálnej geometrie. Analýza vychádza z výpočtu tzv. Dupinovej indikatrix, ktorá popisuje lokálny tvar povrchu v malom okolí bodu, avšak bez použitia diferenciálnych rovníc. To predstavuje výrazný rozdiel oproti klasickým analýzam digitálnych povrchov, ktoré sú ovplyvňované koherentným šumom a priestorovým posunom hraníc geometrických prvkov terénu. K téme napr. Ihring/Hronček/ Holobec 2014; Szabová/Hronček 2015.

8 Mapy (tieňovaný reliéf a morfometrické analýzy) sú v súradnicovom systéme JTSK a výškovom systéme Bpv.

9 V archíve Matice slovenskej je zachovaná písomná zmienka, opis hradiska od neznámeho autora, asi amatéra (Ruttkayovál Ruttkay 2015, 121).

10 J. Katkinová a S. Katkin $(2002,83)$ uvádzajú rozlohu 19,2 ha. Z ich popisu však nie je jasné, čo pokladajú za hranicu výpočtu. Za hranicu nášho výpočtu plochy hradiska (15,56 ha) bola braná os valu, definovaná morfometrickou analýzou (obr. 5).

11 Znázorňuje konvexné, teda vypuklé miesta, v našom prípade val.

12 Poloklieštová brána je brána, ktorej jeden z vyústujúcich valov je vtiahnutý dovnútra. Pri klieštovej bráne by boli oba valy vtiahnuté dovnútra. 


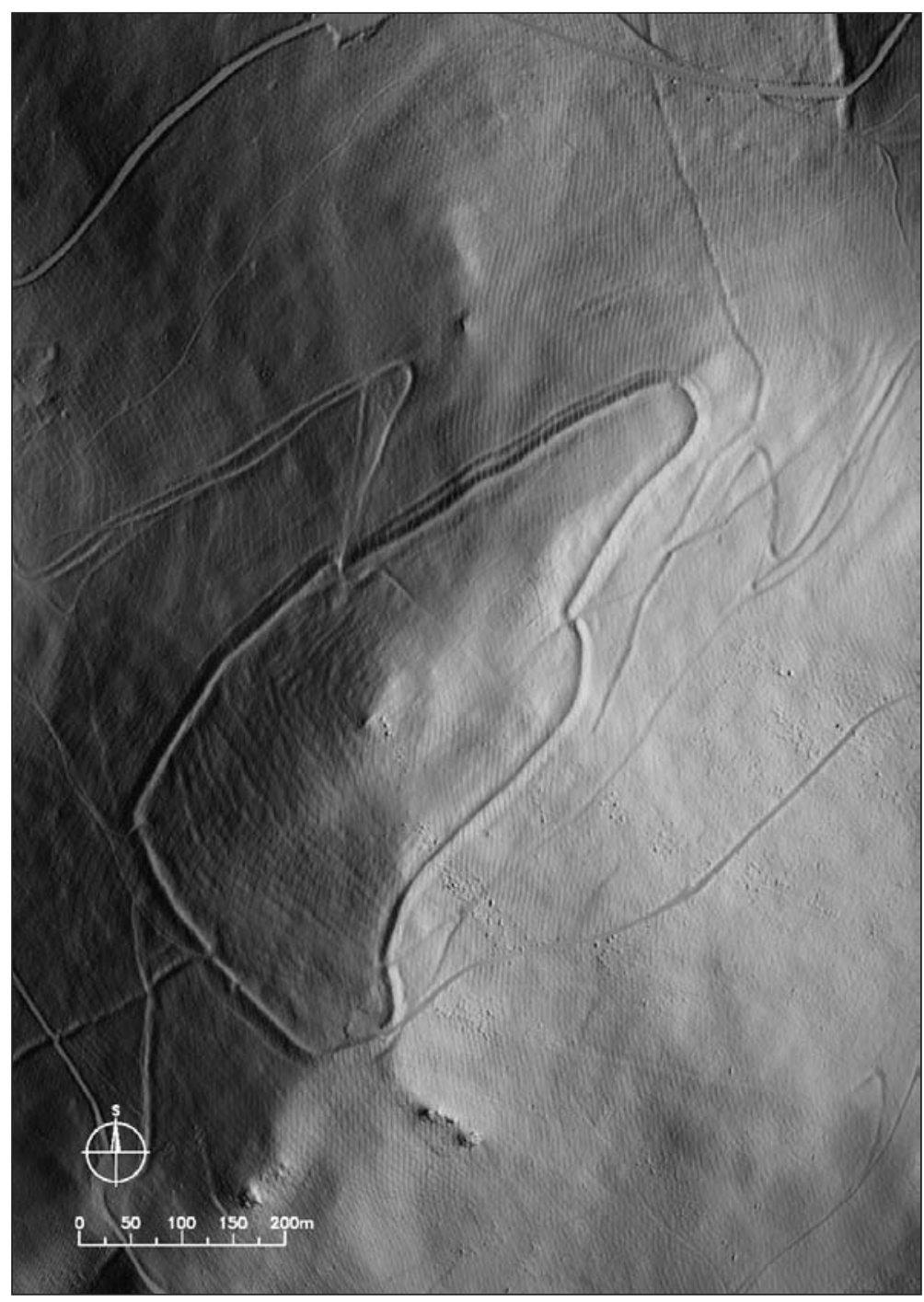

Obr. 2. Vel'ký Tribeč na tieňovanom reliéfe osvetlenom zo severovýchodu (C Katedra leteckej dopravy fakulty PEDAS Žilinskej univerzity v Žiline; Geoaktuál, s. r. o.; GeoProxima, s. r. o.).

Okrem jedinej vyššie zmienenej poloklieštovej brány možno identifikovat’ aj dalšie prerušenia valu (obr. 2; 3; 4). Jedno z nich sa nachádza v západnej časti hradiska, interpretované L. Veliačikom a P. Romsauerom $(1994,87)$ ako d’alšia brána v mieste, kde sa mal nachádzat d’alší vonkajší val. Na základe analýzy konvexít a konkavít možno v týchto miestach pozorovat anomáliu v podobe konvexity, avšak jednoznačne nie je možné určit, či ide o valové opevnenie, resp. o d’alší vonkajší val (obr. 2; 3b, 3c).

Ďalšie prerušenie valu možno identifikovat’ v juhozápadnej (obr. 3d), južnej (obr. 3e) a juhovýchodnej (obr. 3f) časti hradiska, pričom dva z nich sú pravdepodobne umelé a novodobé.

Aj severovýchodná čast valového opevnenia je prerušená (obr. 3g), ako na to upozornil už Š. Janšák (1929, obr. 24n). Podla neho sa v tejto časti nachádzalo tzv. predhradie so vstupom v bode " $\mathrm{m}^{\prime \prime}$ (obr. 1) a podla jeho zamerania malo byt predhradie ${ }^{13}$ tvorené vonkajším valom, ktorý sa v bode "a" a v bode „, b“ napájal na hlavný val hradiska. Na výstupe LLS možno sledovat líniu tohto valu, ktorá však nie je celkom jednoznačná (obr. 2). Najlepšie je čitatelný na výstupe morfometrickej analýzy konvexít, podla ktorej je evidentné, že ide o vypuklinu (konvexitu), resp. val. Avšak na rozdiel od interpretácie S̆. Janšáka (1929, obr. 24) možno predpokladat', že tento „vonkajší val“ sa nenapája na val hradiska, ale pokračuje v línii smerom na sever (obr. 3h; 5). Jeho zmeratelná dĺžka je $727 \mathrm{~m}$. Približnú výšku a šírku tohto líniového valu (ako aj hlavného valového opevnenia) možno určit z priečneho rezu (v tomto prípade rez 2-2'; obr. 5),

\footnotetext{
13 Podobne ho interpretuje aj M. Ruttkay $(2015,318)$.
} 


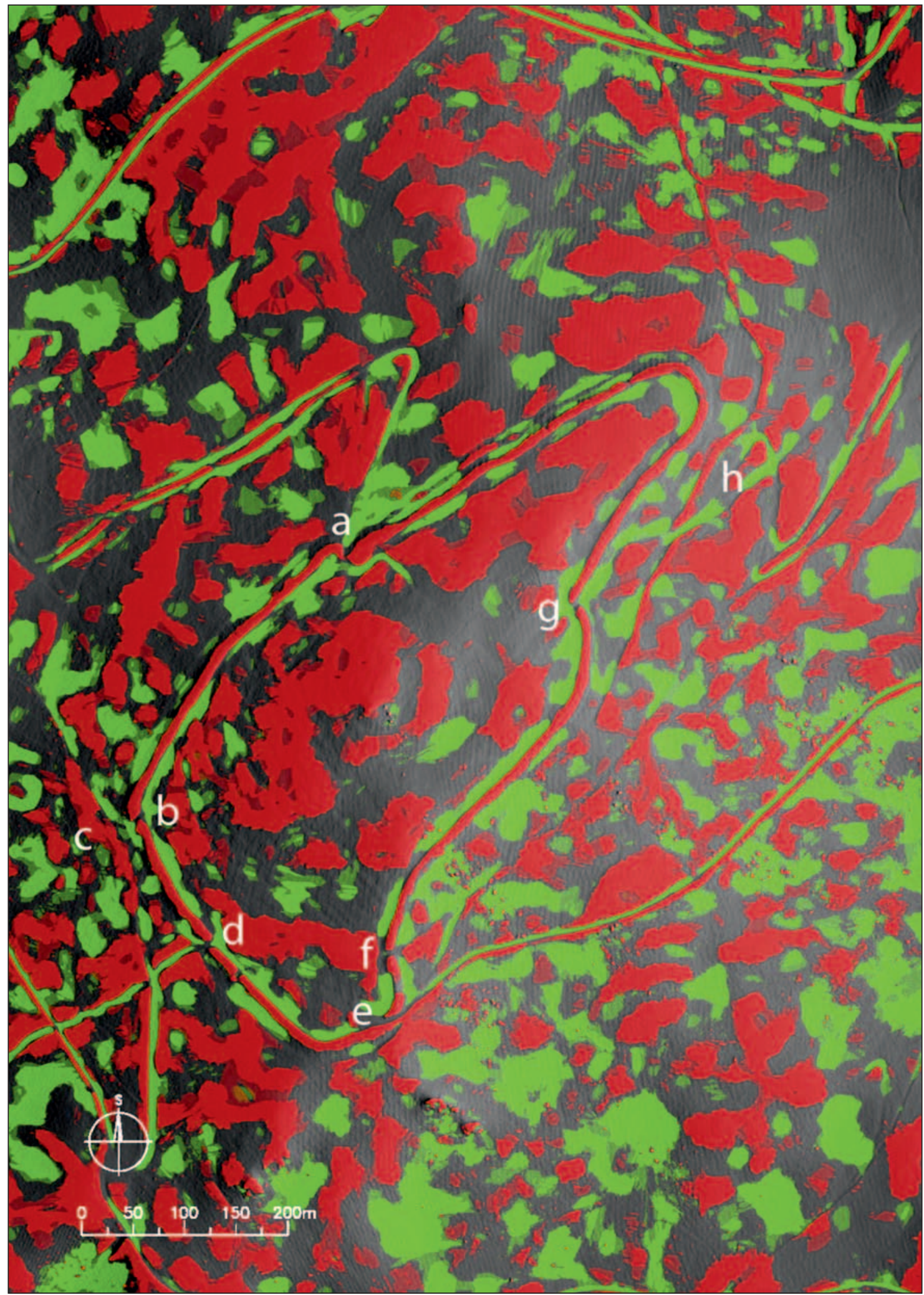

Obr. 3. Vel'ký Tribeč na výstupe morfometrie konvexít (červenou farbou) a konkavít (zelenou farbou) na podklade tieňovaného reliéfu (@ Katedra leteckej dopravy fakulty PEDAS Žilinskej univerzity v Žiline; Geoaktuál, s. r. o.; GeoProxima, s. r. o.). Legenda: a - brána v severozápadnej časti hradiska; b - prerušenie valu v západnej časti opevnenia; c - anomália v podobe konvexity; d - prerušenie valu v juhozápadnej časti; e - prerušenie valu v južnej časti; $\mathrm{f}$ - prerušenie valu v juhovýchodnej časti; $\mathrm{g}$ - prerušenie valu severovýchodnej časti; $\mathrm{h}$ - líniové opevnenie. 


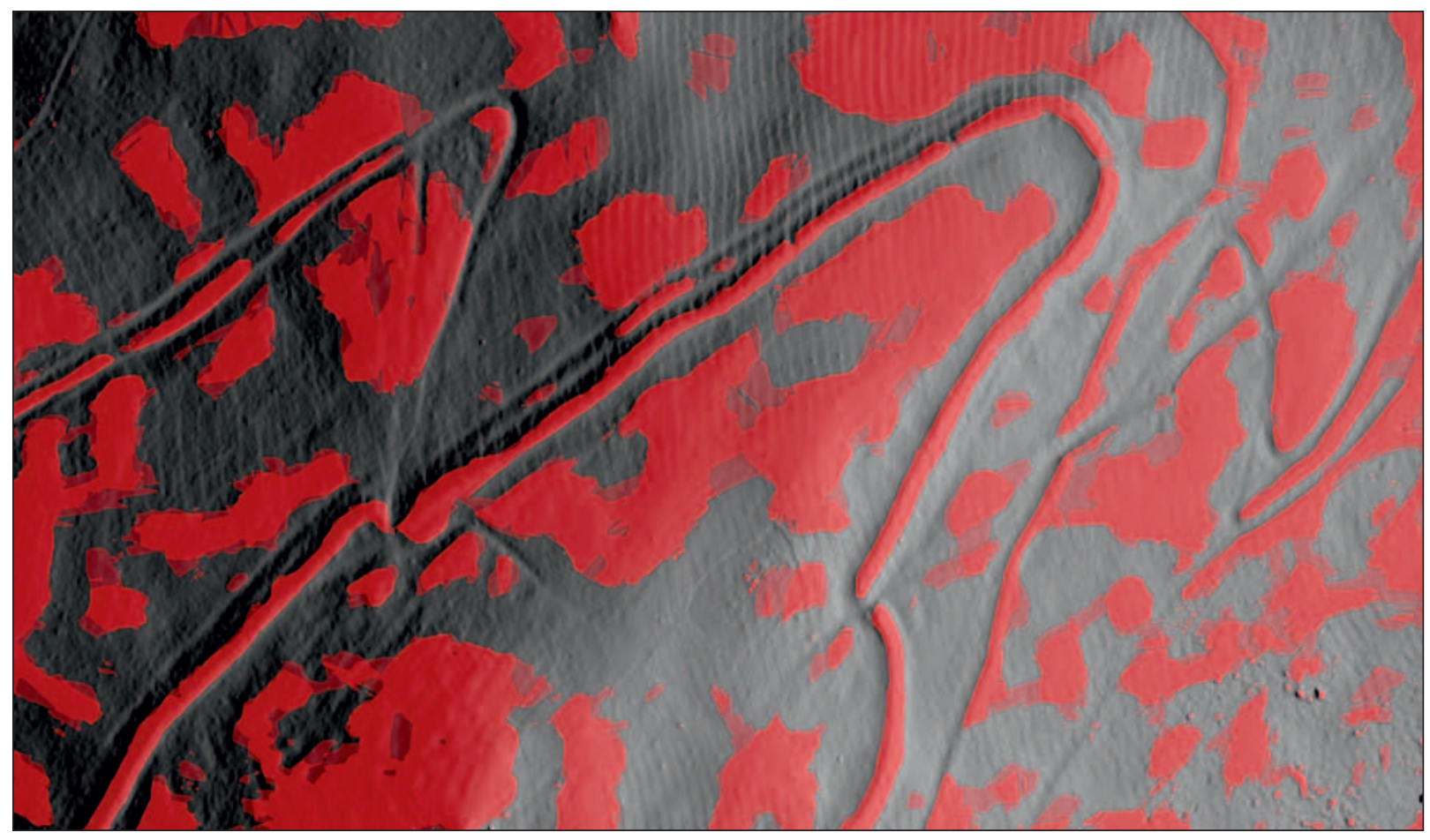

Obr. 4. Vel'ký Tribeč. Detailný pohl’ad na severozápadnú a severovýchodnú bránu na výstupe morfometrie konvexít (červenou farbou) na podklade tieňovaného reliéfu (@ Katedra leteckej dopravy fakulty PEDAS Žilinskej univerzity v Žiline; Geoaktuál, s. r. o.; GeoProxima, s. r. o.).

v ktorom je vyznačený výsledok morfometrickej analýzy konkavít a konvexít. Výška „,vonkajšieho“ valu $\mathrm{v}$ reze $2-2^{\prime 14}$ asi $0,5 \mathrm{~m}$ a jeho šírka je $8,2 \mathrm{~m}$ (Borza 2017).

Valové opevnenie s obvodom $1846 \mathrm{~m}^{15}$ sa dodnes $\mathrm{v}$ teréne nachádza s rôznou úrovňou zachovania (obr. 6; 7). V 90. rokoch 20. stor., ako aj na začiatku 21. stor. dosahovala výška valu približne 1-2 m (Katkinová/Katkin 2002, 83; Veliačik/Romsauer 1994, 87). Podla J. Ruttkayovej a M. Ruttkaya $(2015,121)$ sú valy na väčšine areálu zachované väčšinou do výšky menej ako $1 \mathrm{~m}$. Väčšia výška je doložená iba výnimočne, a to $\mathrm{v}$ oblasti severozápadnej brány. Výšku valového opevnenia možno sledovat’ v rezoch vyznačených na pôdoryse (obr. 5). V severozápadnej časti opevnenia, v reze 1-1' je výška valu asi 0,6 a šírka 8,2 m. V severovýchodnej časti opevnenia, v reze $2-2$ je výška valu približne $0,9 \mathrm{~m}$ a šírka takmer $9,4 \mathrm{~m}$. V južnej časti valu, v reze 3-3'je výška valu asi 0,8 m a š́rka zhruba 7,2 m (Borza 2017).

Na tieňovanom reliéfe je možné pozorovat’ aj terénne depresie $v$ areáli hradiska, predovšetkým štvoruholníkový útvar v jeho východnej časti (Ruttkay 2015, 318). Ten bolo možné bližšie špecifikovat terénnou prospekciou zo začiatku 21. stor. Približne 100-150 m juhovýchodne od vrcholu kopca boli zachované obvodové múry (do výšky 0,5 m) obdížnikového objektu s rozmermi 60-70 x 25-30 m (obr. 8). V objekte, ani v jeho okolí, neboli nájdené žiadne artefakty (Katkinová/Katkin 2002, 83). Objekt je možné identifikovat na tieňovanom reliéfe, avšak na výstupe morfometrie konkavít a konvexít tento útvar nie je pozorovatelný.

Okrem vyššie zmienených terénnych reliktov v hradisku možno pozorovat aj ostatné depresie ako cesty, pramene - zdroje vody. Prostredníctvom morfometrie konkavít a konvexít sú lahšie rozpoznatelné, ${ }^{16}$ resp. je ich možné bližšie definovat' než na výstupe LLS.

14 Rez 2-2' je vedený valovým opevnením hradiska, ako aj líniovým valom (obr. 5).

15 Obvod hradiska je vypočítaný v osi valu (obr. 5). Zaujímavé je, že aj výpočet Š. Janšáka (1929, 17) z roku 1929 obvodu valu je podobný nášmu meraniu, t. j. $1882 \mathrm{~m}$.

16 Podla tieňovaného reliéfu niekedy nie je možné rozpoznat cestu od valu. Na základe morfometrie konkavít a konvexít, ktoré sú definované inou farbou, sú tieto depresie lahko rozpoznatelné. 

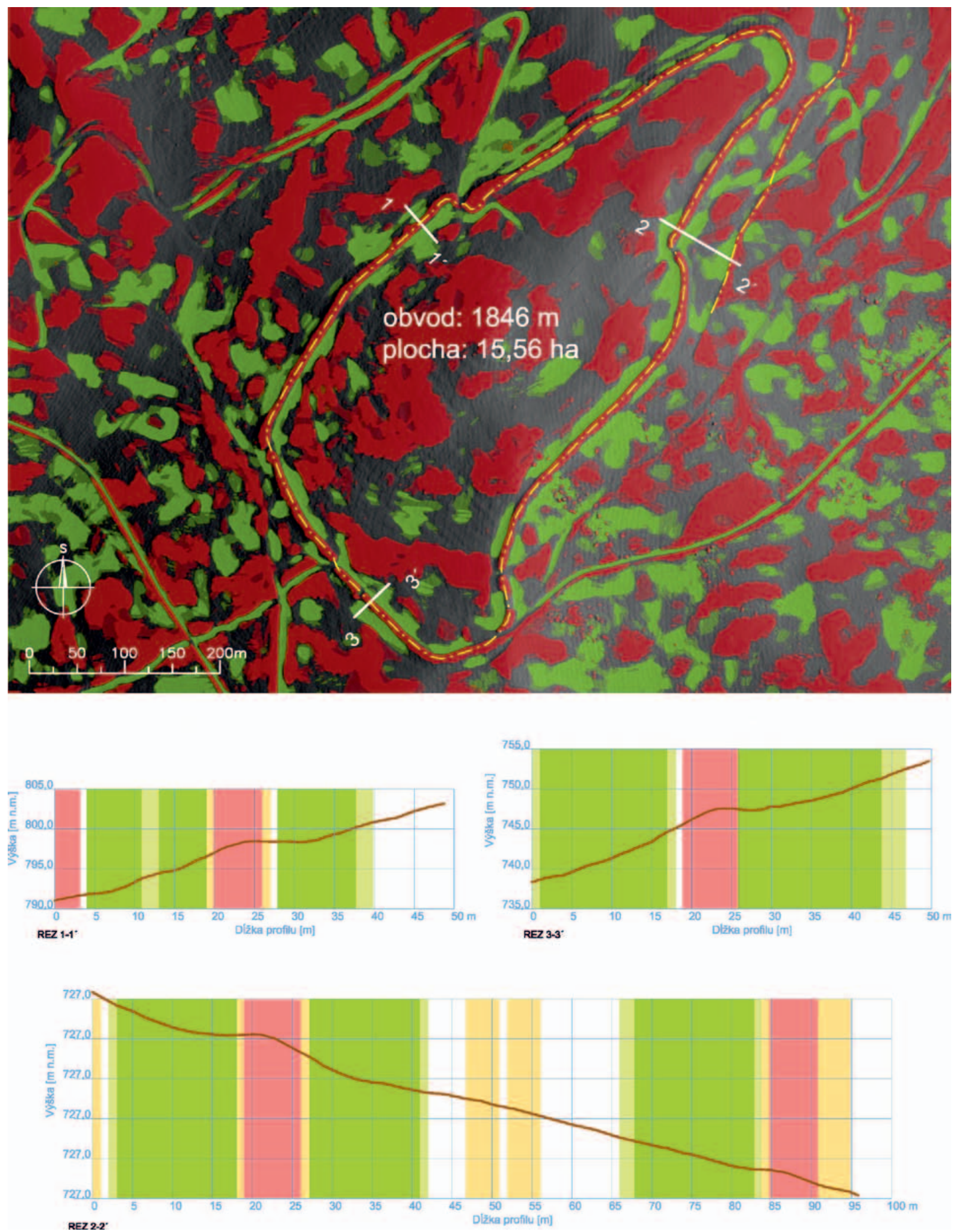

Obr. 5. Vel'ký Tribeč. Geometrické údaje hradiska a priečne rezy, v ktorých je vyznačený výsledok morfometrickej analýzy konkavít a konvexít. 


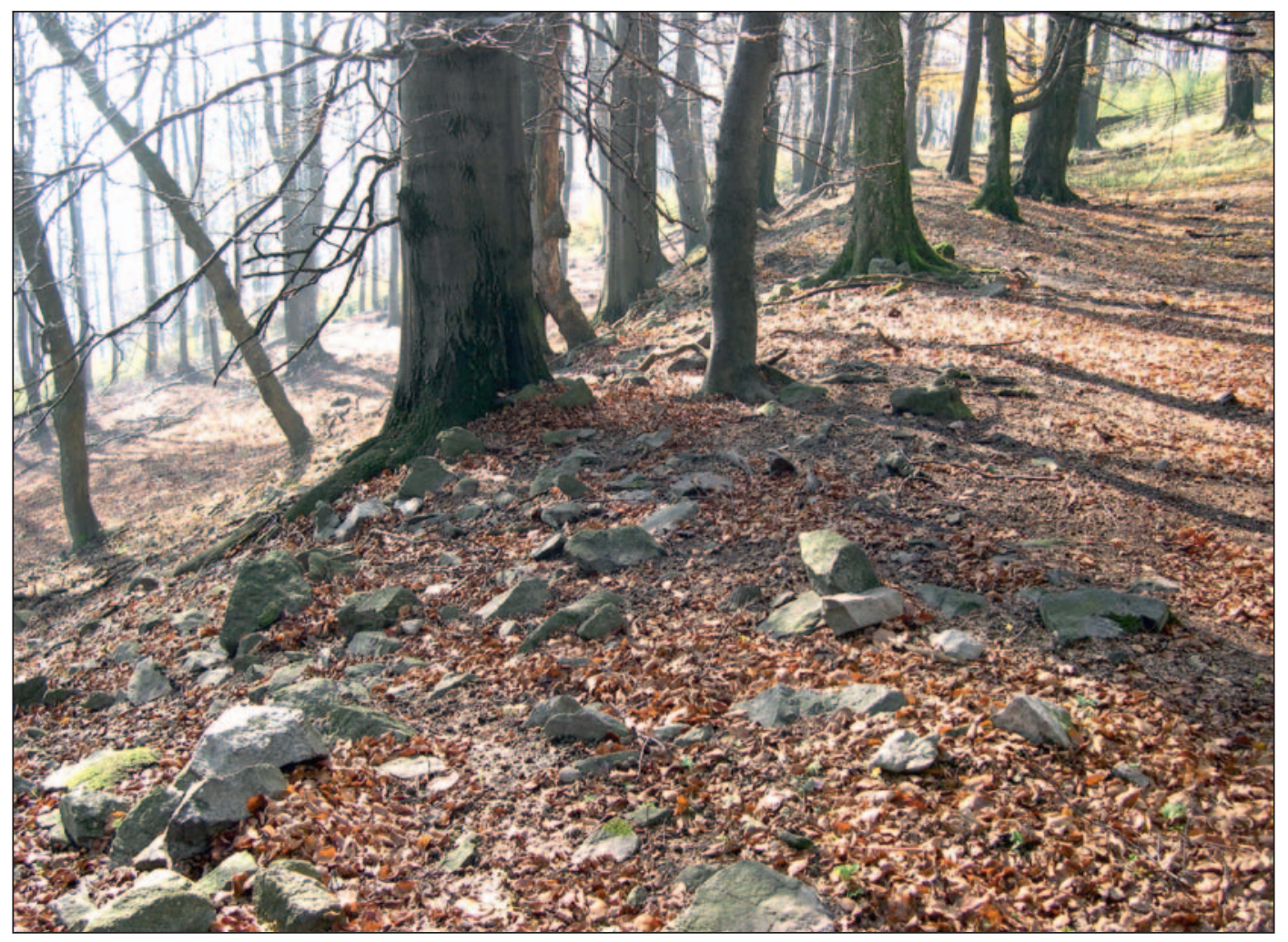

Obr. 6. Vel'ký Tribeč. Pozostatky valového opevnenia na hradisku. Stav z roku 2004. Foto P. Bisták.

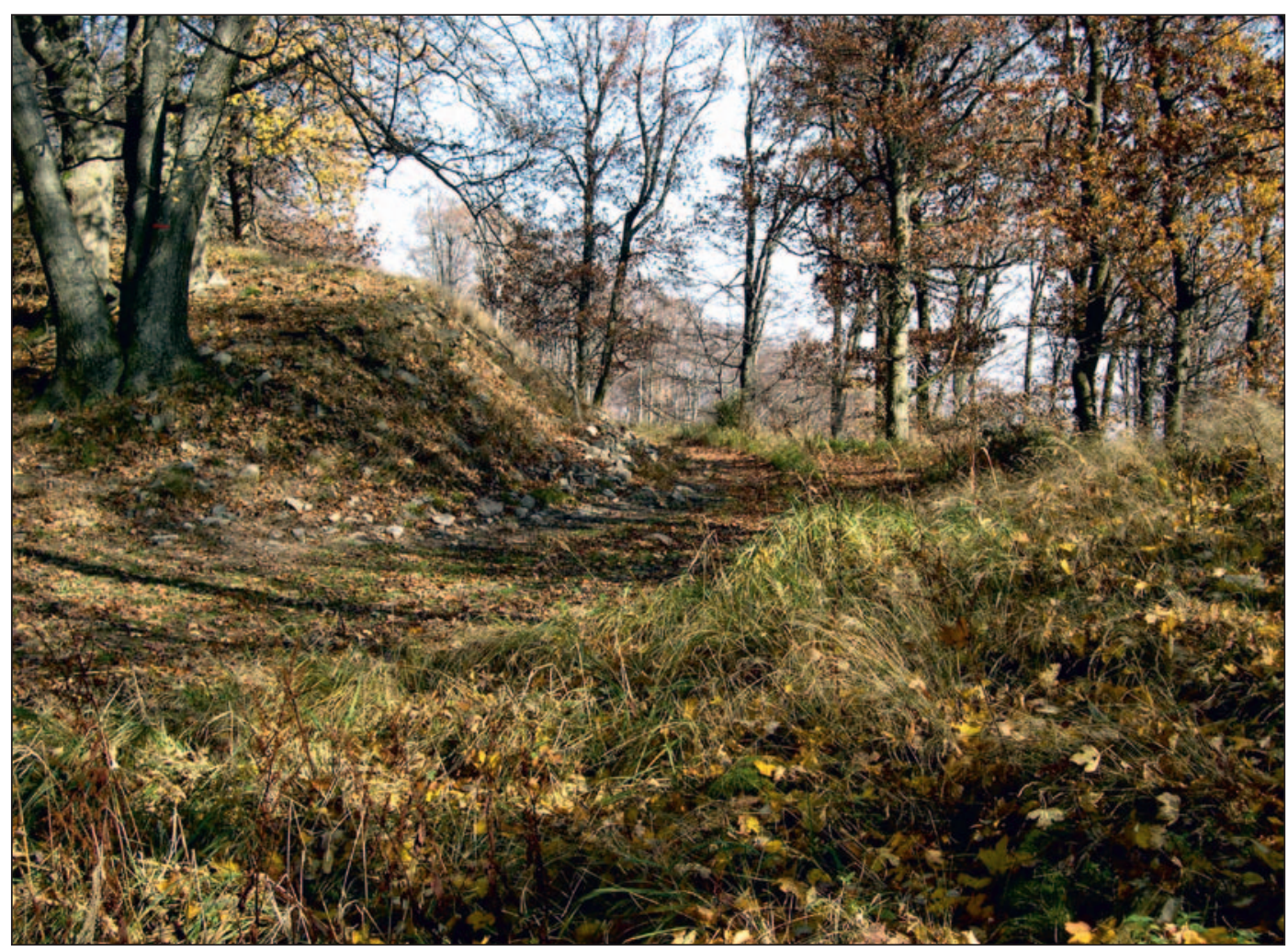

Obr. 7. Vel'ký Tribeč. Valové opevnenie hradiska prerušené novou lesnou cestou. V týchto miestach je val omnoho vyšší, než v rezoch (obr. 5). Stav z roku 2004. Foto P. Bisták. 


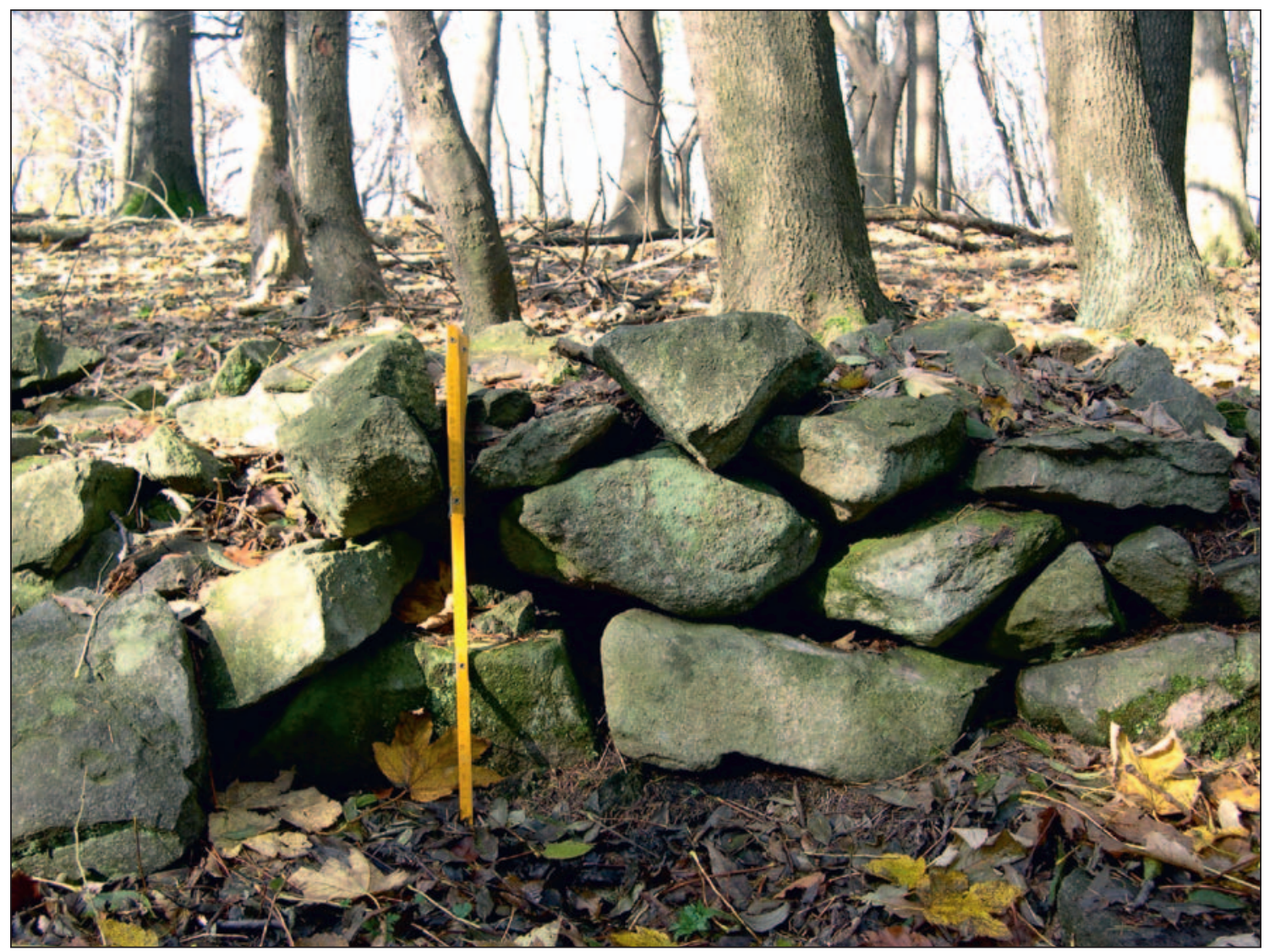

Obr. 8. Vel'ký Tribeč. Obvodový múr objektu z nasucho kladených kameňov na hradisku. Stav z roku 2004. Foto P. Bisták.

\section{Velčice - stredoveké opevnené sídlo ${ }^{17}$}

Severne od Velčíc, na vyvýšenine zovretej Svincom a sútokom bezmenného potoka s Čerešňovým potokom, v polohe Kožová, bol terénnou prospekciou v roku 1964 objavený opevnený útvar (Habovštiak 1964), ktorého zameranie bolo publikované v 80. rokoch (obr. 9). Na tejto lokalite boli uskutočnené viaceré povrchové prieskumy, ${ }_{18}^{18}$ ako aj geofyzikálny prieskum s cielom spresnit dovtedy známe informácie o nálezisku (Tirpák 2003). Neskôr skúmal lokalitu I. Kuzma aj letecky (Ruttkay 2004, 160). V poslednom období bol pomocou leteckého laserového skenovania vytvorený tieňovaný reliéf, na ktorom možno pozorovat priebeh opevnenia a 3D model tohto opevnenia (Ruttkay 2015, 325, obr. 25; Ruttkayová/Ruttkay 2015, 120).

Terénne relikty tunajšieho hrádku, okrem tieňovaného reliéfu (obr. 10), možno ešte detailnejšie sledovat' na výstupe morfometrickej analýzy konkavít a konvexít (obr. 11). Zo získanej analýzy, ktorej výsledky sú evidentné aj v rezoch (rez 1-1'; obr. 12) je zrejmé, že opevnenie bolo tvorené vnútorným valom, priekopou a vonkajším valom. Zvyšky opevnenia sú dodnes zachované v celej severnej, západnej a južnej časti (obr. 13). Podla tieňovaného reliéfu (obr. 10), ako aj detailného zamerania hrádku A. Habovštiakom (obr. 9) sa opevnenie v severovýchodnej časti vytráca, resp. prechádza do strmého svahu, brehu potoka. Na výstupe morfometrie konkavít a konvexít možno v severovýchodnej časti opevnenia sledovat' konvexitu, ktorú možno pokladat’ za pokračovanie valu v tejto časti (obr. 11). Na východnej strane chýba priebeh opevnenia a na juhovýchodnej strane je viditel'né skôr na tieňovanom reliéfe, než na výstupe morfometrie konkavít a konvexít. Prekrytím oboch výstupov možno rekonštruovat priebeh

17 Podla A. Habovštiaka $(1985,321)$ ide o opevnený zemepanský dvorec. Najnovšie F. Jaššo (2009) označuje toto opevnenie ako hrádok - opevnené sídlo nižšej šlachty. Podobne aj J. Ruttkayová a M. Ruttkay $(2015,120)$ ho nazývajú hrádkom.

18 K tomu: Habovštiak 1964; 1968; Jaššo 2007, 134; 2009, 189; Ruttkay 2004, 160; Ruttkayová/Ruttkay 2015, 120. 


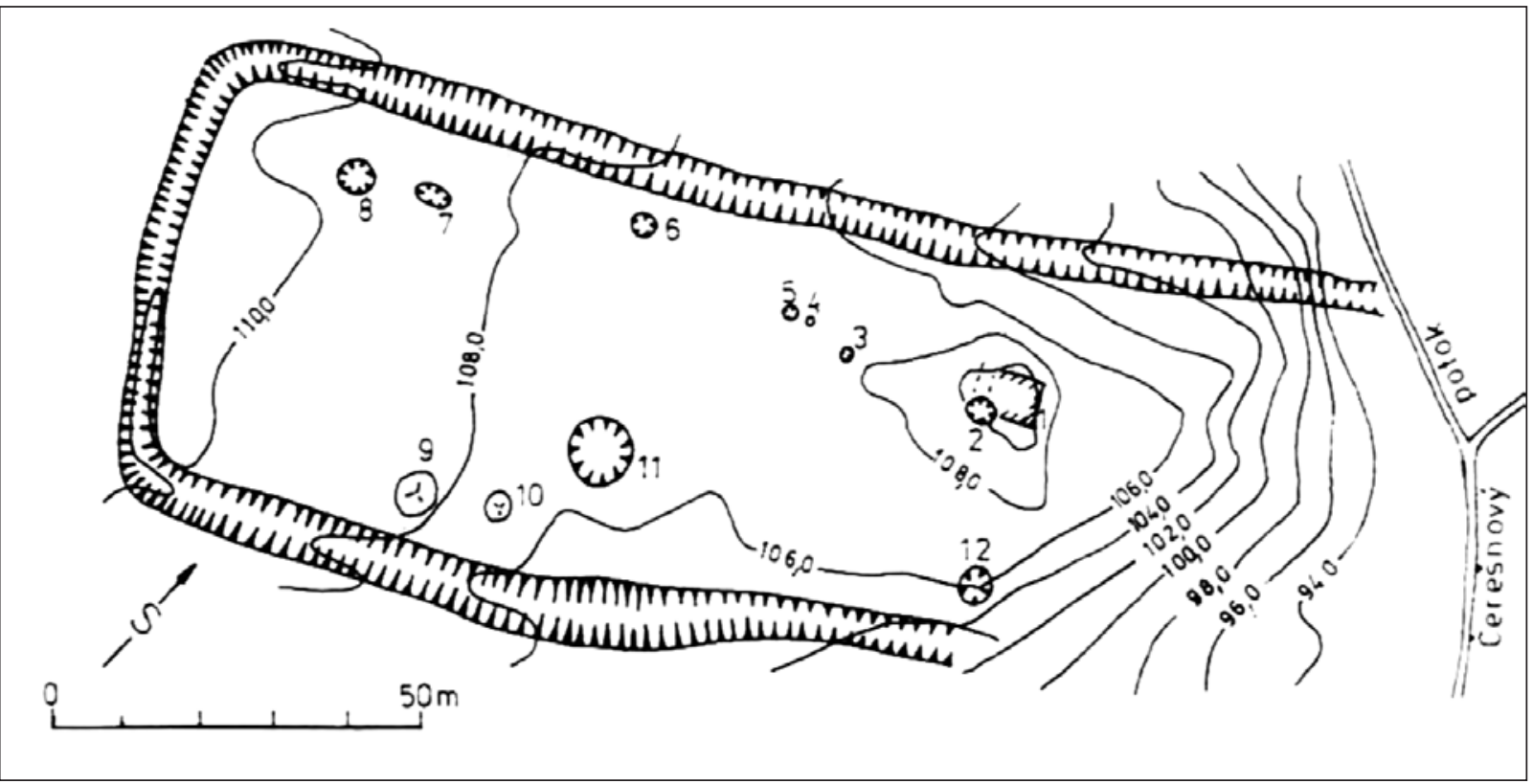

Obr. 9. Opevnené sídlo vo Velčiciach. Zameranie podla A. Habovštiaka $(1985,321)$.

opevnenia v jeho chýbajúcej časti (obr. 12). Na základe toho možno vypočítat plochu, resp. rozlohu vnútornej plochy, ktorá je 0,74 ha. ${ }^{19}$ Predpokladané rozmery vnútornej plochy sú $54 \times 156 \mathrm{~m} .{ }^{20}$ Zmeratel’ná dížka zachovanej časti opevnenia meraného v osi priekopy je $325 \mathrm{~m}$. Z priečneho rezu je možné určit aj rozmery zvyškov tejto fortifikácie (obr. 12). V severnej časti opevnenia (rez 1-1') má vonkajší val zachovanú výšku $0,4 \mathrm{~m}$ a šírku 3,5 m. Vnútorný val má výšku 0,2 m a šírku 2,7 m. Híbka priekopy je 0,4 a jej šírka je 3,7 m. V juhovýchodnej časti (rez 1-1') má vnútorný val zachovanú výšku $0,3 \mathrm{~m}$ a šírku až 6,5 m. Vonkajší val má zachovanú výšku $0,3 \mathrm{~m}$ a šírku 4,4 $\mathrm{m}$. Híbka priekopy medzi valmi je 0,4 $\mathrm{m}$ a šírka 4,0 m (obr. 12).

Na tieňovanom reliéfe, ako aj na výstupe morfometrie je viditelné prerušenie opevnenia $v$ jeho severnej, ako aj v južnej časti (obr. 10; 11a, b). ${ }^{21}$ Na východnej strane, v mieste miernej vyvýšeniny, $\mathrm{v}$ areáli opevnenia sa zachovali stopy po vežovitej stavbe (obr. 11c; 14; 15) obdížnikového pôdorysu s rozmermi 6,5 x 7,3 m (Jaššo 2009, 189). Z vlastného hrádku zostali pravdepodobne len základy. V reze 2-2'možno sledovat' konvexné časti aj s metrickými údajmi (obr. 12).

Z nameraných výsledkov, v porovnaní s výsledkami A. Habovštiaka (1964), je evidentné, že za posledných 33 rokov dochádza $\mathrm{k}$ značnému rozpadu valového opevnenia, ako aj $\mathrm{k}$ zanášaniu priekopy.

V areáli opevnenia, ale aj mimo neho je možné na tieňovanom reliéfe pozorovat rôzne terénne depresie, ktoré doposial' nie sú jednoznačne interpretované (obr. 11d). Podla $F$. Jašša $(2007,134 ; 2009,189)$ ide o zvyšky objektov kruhového a obdĺžnikového pôdorysu so zvyškami kamenných podmuroviek. Aj geofyzikálnym prieskumom boli vo vnútornom areáli opevnenia rozpoznané d’alšie anomálie izometrického tvaru, ktorých funkcia zatial nie je zrejmá. Tieto objekty možno pozorovat’ aj na výstupe morfometrie, kde sa javia ako okrúhle a oválne konkavity (obr. 11). Pre dokumentačné účely je možné tieto útvary detailne metricky zdokumentovat'.

Východne od tejto polohy sa našli pozostatky po umelom prehradení potoka v dížke $29 \mathrm{~m}$ (obr. 11e). ${ }^{22}$ Zachovaná výška hrádze je $0,8 \mathrm{~m}$ a šírka 3,6 $\mathrm{m}$ (obr. 12). V západnom svahu terasy oproti hrádzi identifikoval A. Habovštiak $(1985,322)$ zásek s rozmermi $8 \times 11 \mathrm{~m}$ a hlbkou $3 \mathrm{~m}$, so šikmo sa zvažujúcimi stenami a rovným dnom. Túto konkavitu je možné sledovat aj na výstupe morfomertie (obr. 11f; 12). Šírka tejto

\footnotetext{
19 Za hranicu nášho výpočtu plochy hradiska bola braná os vnútorného valu, definovaná morfometrickou analýzou (obr. 12).

20 Rozmery hrádku uvádzajú viacerí autori: podl’a F. Jašša $(2009,189)$ a M. Ruttkaya $(2015,319)$ je to 56 x 115 m, podla A. Habovštiaka (1964) 37 × $85 \mathrm{~m}$.

21 Na zameraní A. Habovštiaka nie sú zamerané žiadne prerušenia vo forme vstupu do opevnenia (obr. 9).

22 Podl’a A. Habovštiaka $(1985,322)$ má dížku 38 m.
} 


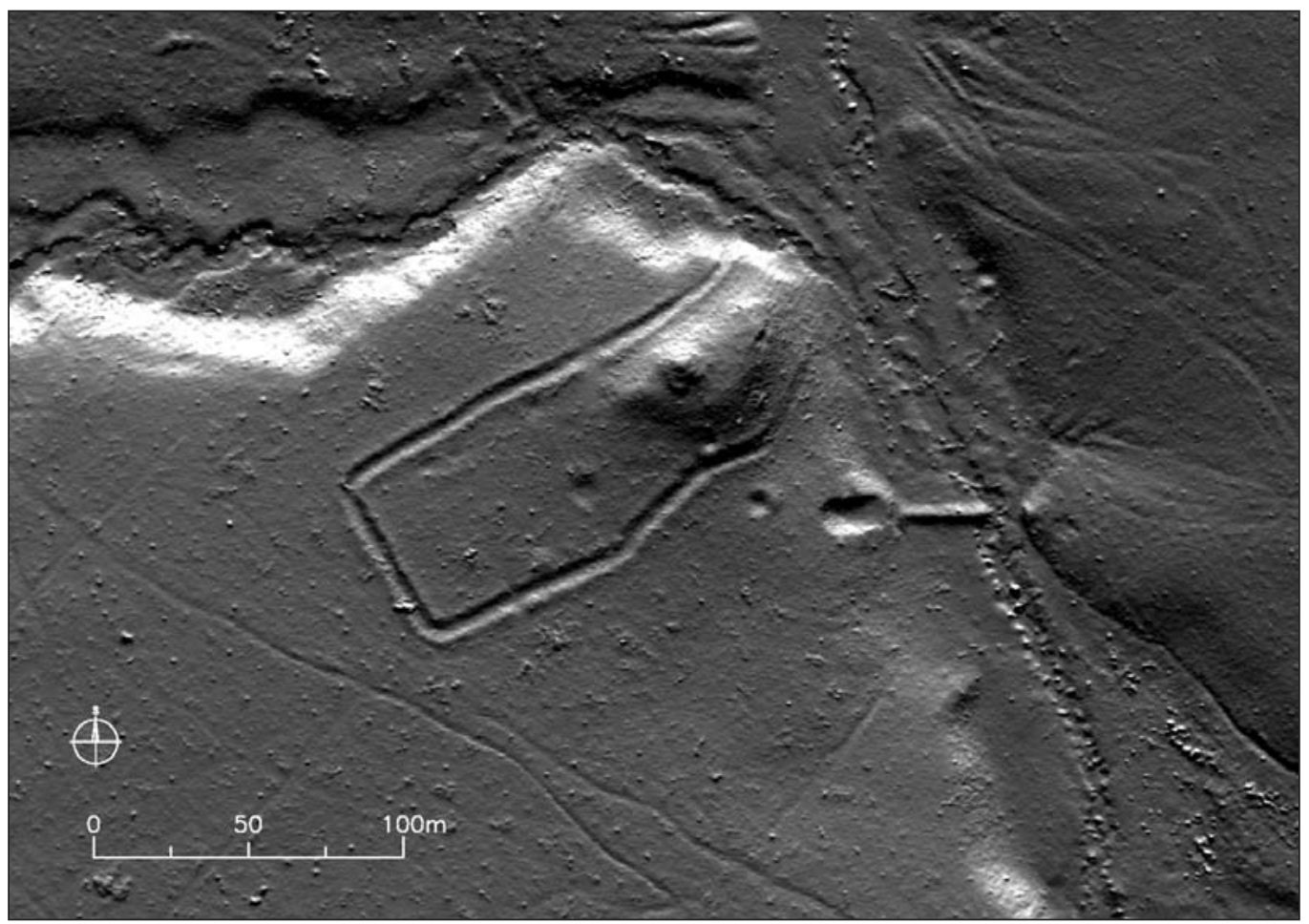

Obr. 10. Opevnené sídlo vo Velčiciach na tieňovanom reliéfe osvetlenom zo severu (@ Katedra leteckej dopravy fakulty PEDAS Žilinskej univerzity v Žiline; Geoaktuál, s. r. o.; GeoProxima, s. r. o.).

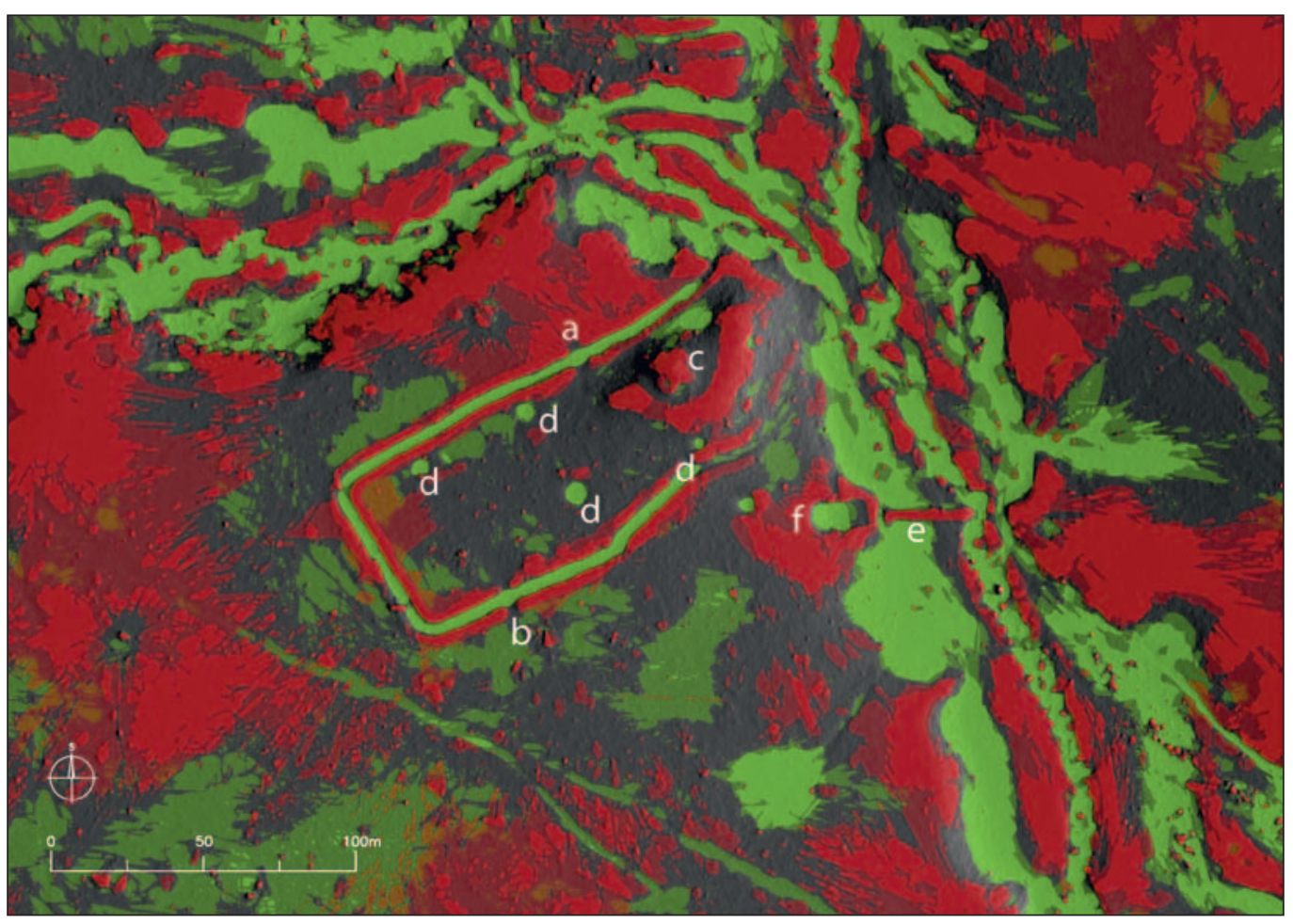

Obr. 11. Opevnené sídlo vo Velčiciach na výstupe morfometrie konvexít (červenou farbou) a konkavít (zelenou farbou) na podklade tieňovaného reliéfu (C Katedra leteckej dopravy fakulty PEDAS Žilinskej univerzity v Žiline; Geoaktuál, s. r. o.; GeoProxima, s. r. o.). Legenda: a - prerušenie valu v severnej časti; $b$ - prerušenie valu v južnej časti; c - stopy po vežovitej stavbe; $d$ - terénne depresie $\mathrm{v}$ areáli opevnenia; $\mathrm{e}$ - umelé prehradenie potoka; $\mathrm{f}$ - nádrž. 

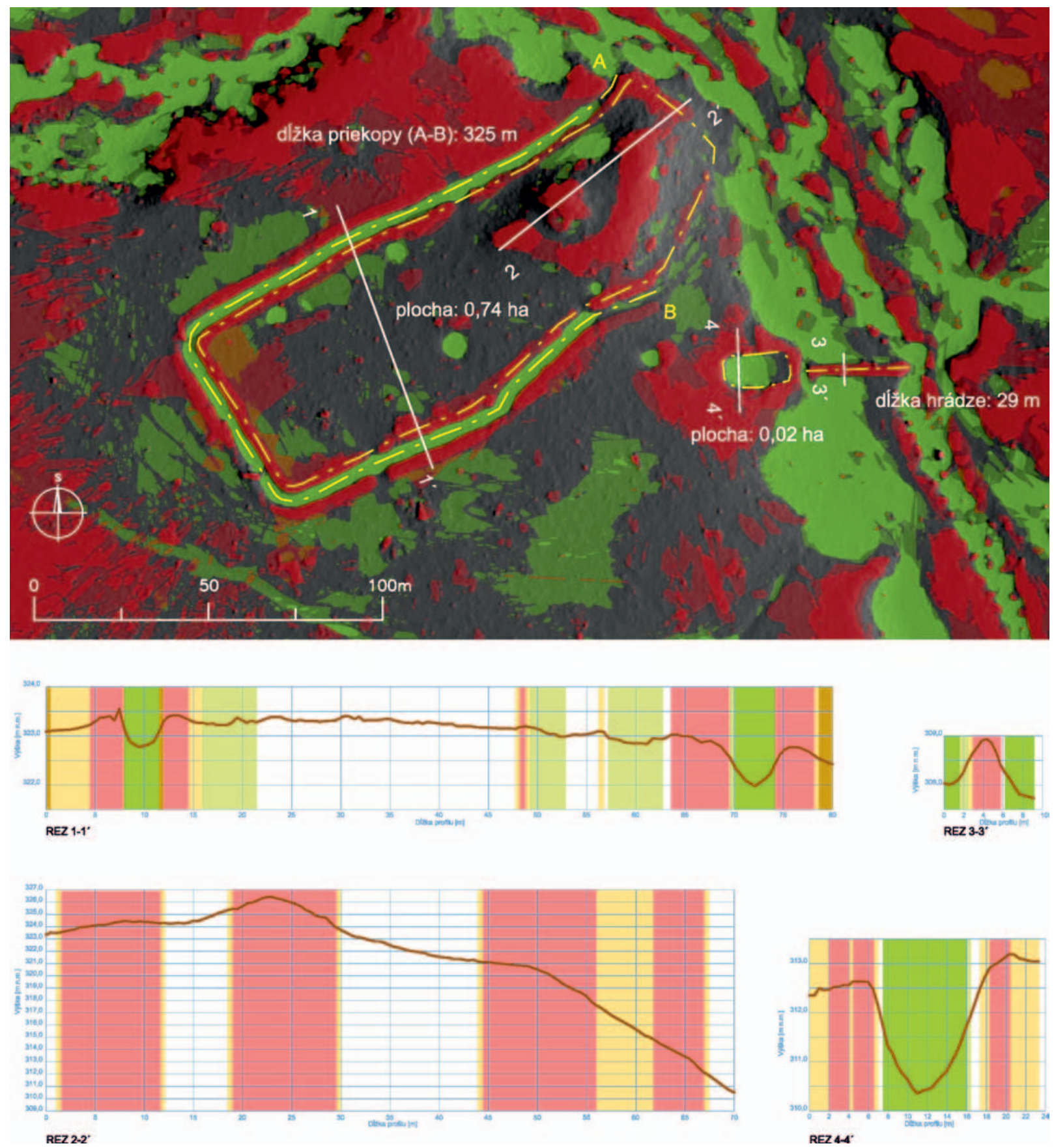

Obr. 12. Opevnené sídlo vo Velčiciach. Geometrické údaje a priečne rezy, v ktorých je vyznačený výsledok morfometrickej analýzy konkavít a konvexít.

konkavity je 10,4 m a híbka 1,9 m. Vnútorná plocha je 0,02 ha. Umelá nádrž mohla slúžit ako rybník, alebo ako nádrž pre technické účely, napr. pre mlyn v stredoveku, resp. novoveku (Bisták/Borzová 2018, 223; Ruttkayová/Ruttkay 2015, 120). ${ }^{23}$

Okrem toho pri potoku boli objavené aj iné anomálie, ktorých funkcia zatial' nie je známa. Mohlo íst o pozostatky objektov spojených s ryžovaním zlata alebo tažobné jamy na piesok súvisiace $\mathrm{s}$ výrobou skla v ned’alekej zaniknutej sklárni (Ruttkay 2015, 325; Ruttkayová/Ruttkay 1991, 120).

${ }^{23}$ Mlyn je na tomto mieste doložený na prvom vojenskom mapovaní z 80. rokov 18. stor. V písomných prameňoch sa tunajší mlyn spomína až v listine o založení sklárne z roku 1856 (Bisták/Borzová 2018, 223). 


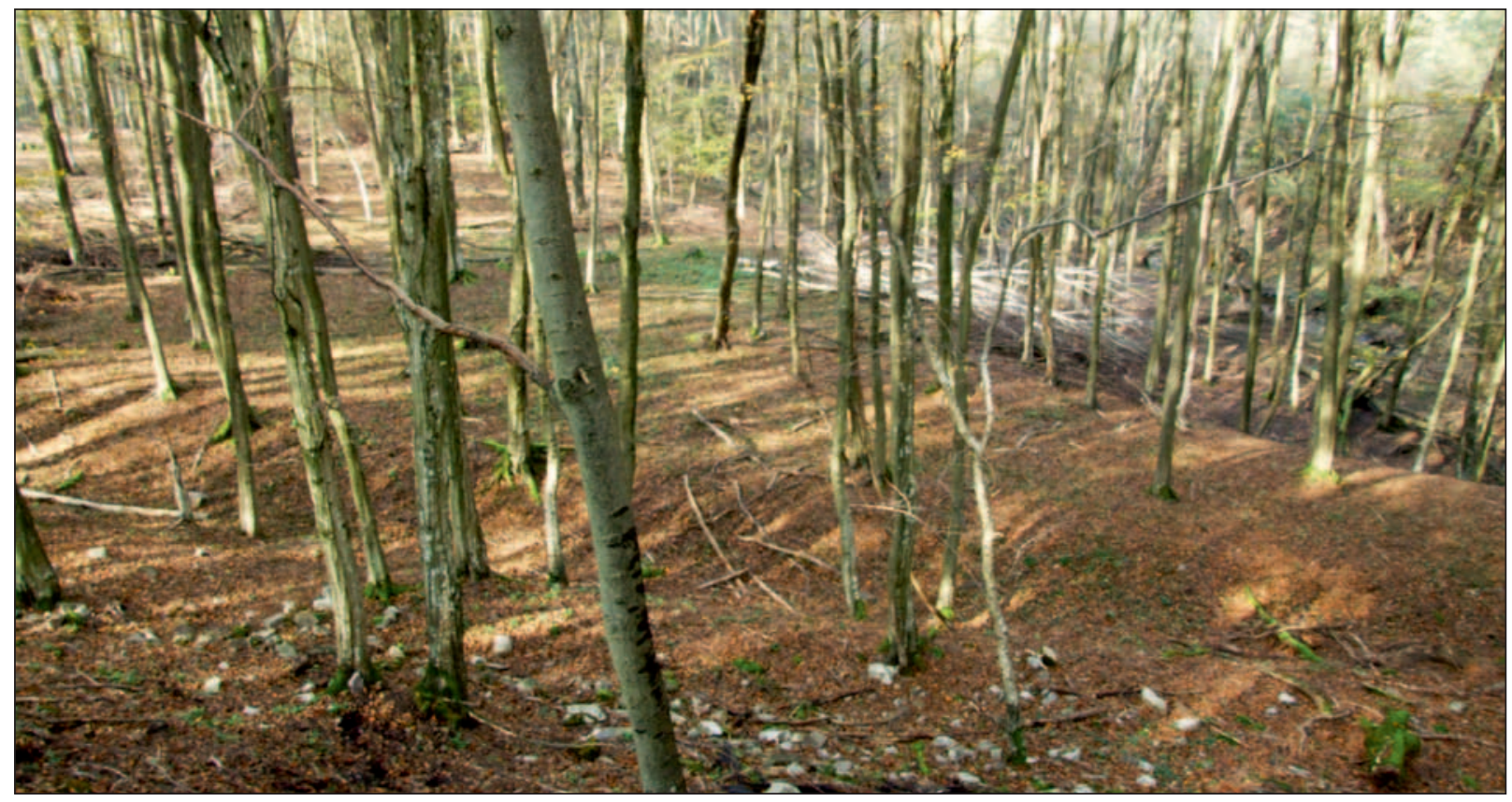

Obr. 13. Velčice. Priebeh priekopy v severnej časti areálu stredovekého hrádku. Stav z roku 2014. Foto P. Bisták.

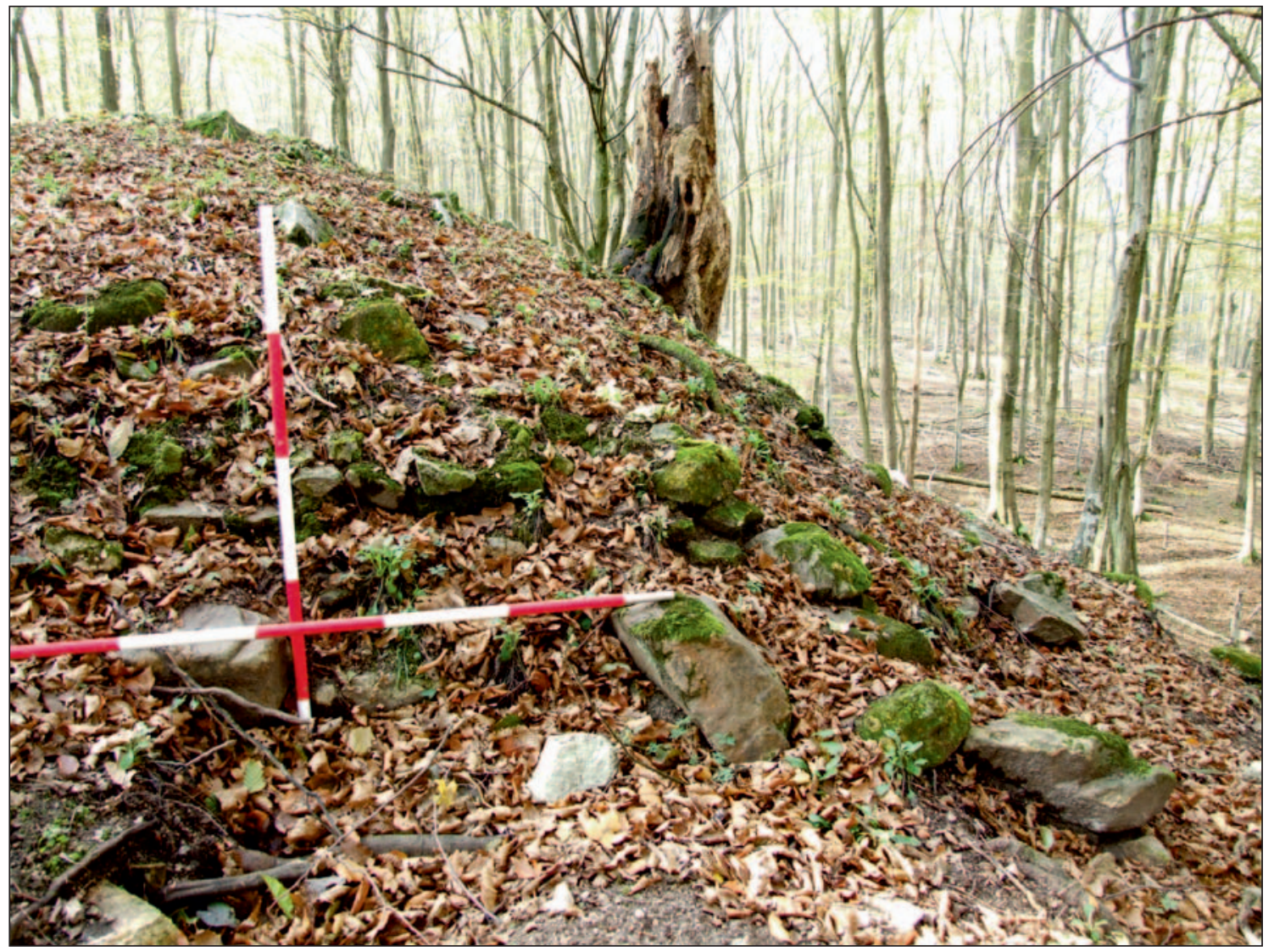

Obr. 14. Velčice. Pozostatky vežovitej stavby, rozrušená koruna muriva veže stredovekého hrádku. Stav z roku 2014. Foto P. Bisták. 


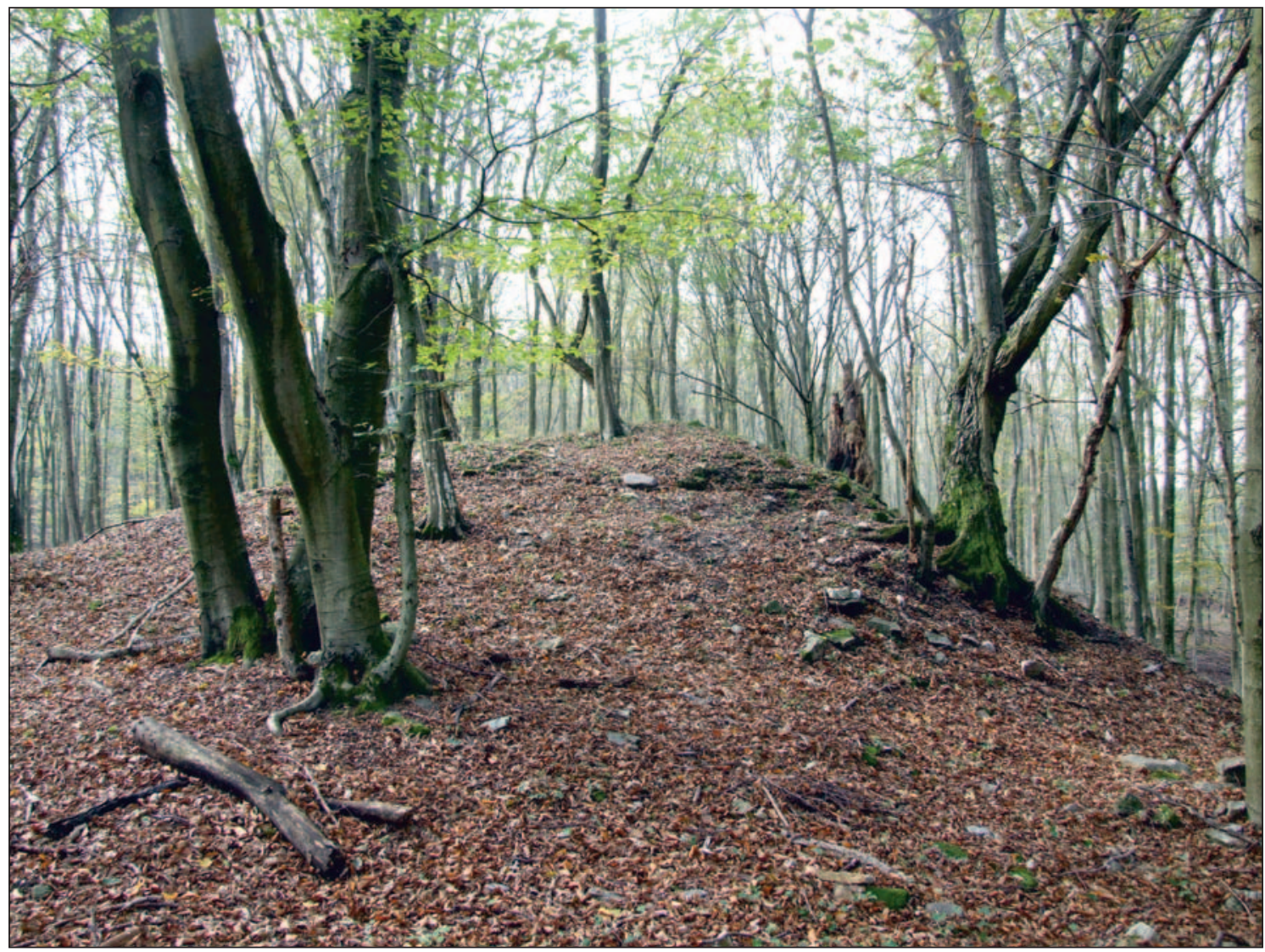

Obr. 15. Opevnené sídlo vo Velčiciach. Vyvýšenina s pozostatkami murovanej veže. Stav z roku 2014. Foto P. Bisták.

V skúmanej polohe sa terénnou prospekciou a zberom podarilo nájst' nespočetné množstvo keramických zlomkov z vrcholného stredoveku, zlomky pálených tehál, opracovaných kameňov a železné klince (Jaššo 2009, 189; Ruttkay 2004, 160; Ruttkayová/Ruttkay 2015, 120).

\section{Studený hrad - stredoveké opevnené sídlo}

Na kremencovej hôrke, približne 500 m južne od hradu Gýmeš, sa nachádzajú ruiny opevnenia. Lokalita, ktorá sa na starších mapách označuje aj ako Várhegy, patrila k tým výšinným polohám, ktoré boli prospekciou skúmané už od polovice minulého stor. (Habovštiak 1968, 44; Porubský 1956) ${ }^{24}$ až dodnes (napr. Baxal BorzoválJahn 2016, 38; Bisták/Daňo 2006; Borzová/Pažinová 2009, 41). Na tejto lokalite sa doteraz neuskutočnil žiaden deštruktívny archeologický výskum. Opevnená poloha bola už v minulosti geodeticky zameraná T. Szaboóm a M. Bartíkom (obr. 16), naposledy J. Šindelářom a B. Váchom (Baxa/BorzoválJahn 2016, 39).

Z doterajších výsledkov možno usúdit, že ide o malé opevnenie s oválnou plošinou, ${ }^{25} \mathrm{ktorá} \mathrm{je} \mathrm{chráne-}$ ná vonkajším valom a vnútornou priekopou (obr. 17-19). Na tieňovanom reliéfe, ako aj výstupe morfometrie konkavít a konvexít je vidiet, že val je najlepšie zachovaný vo východnej a južnej časti opevnenia (obr. 17; 18). V mieste rezu $1-1^{\prime}$ má priekopa šírku $4,9 \mathrm{~m}$ a híbku $0,5 \mathrm{~m}$ (obr. 20). ${ }^{26} \mathrm{~V}$ niektorých častiach, napr. v juhozápadnej časti je úplne zanesená (obr. 20). Naopak, v severovýchodnej aj juhovýchodnej časti je priekopa v teréne vel’mi výrazná a má híbku viac ako $1 \mathrm{~m}$. Na výstupe morfometrie konkavít a konvexít je priekopa najzretel’nejšie viditel’ná v južnej časti, a to v dížke $32 \mathrm{~m}$.

\footnotetext{
24 V literatúre sa objavuje už v roku 1864 ako „Hidegvár“, ktorý spomína Frigyes Pesti vo svojom miestopise. Spomína ho aj E. Soós, avšak s nesprávnou lokalizáciou. http://varak.hu/Pozoruhodnosti/index/2473-Jelenec-Hidegvar [27. 3. 2017]

25 Podla M. Bónu $(2011,28)$ má opevnená plošina rozmery 40 x 70 m.

26 Podla Á. Karcaga má priekopa híbku 2 m a šírku 5 m. http://varak.hu/Pozoruhodnosti/index/2473-Jelenec-Hidegvar [27. 3. 2017]
} 


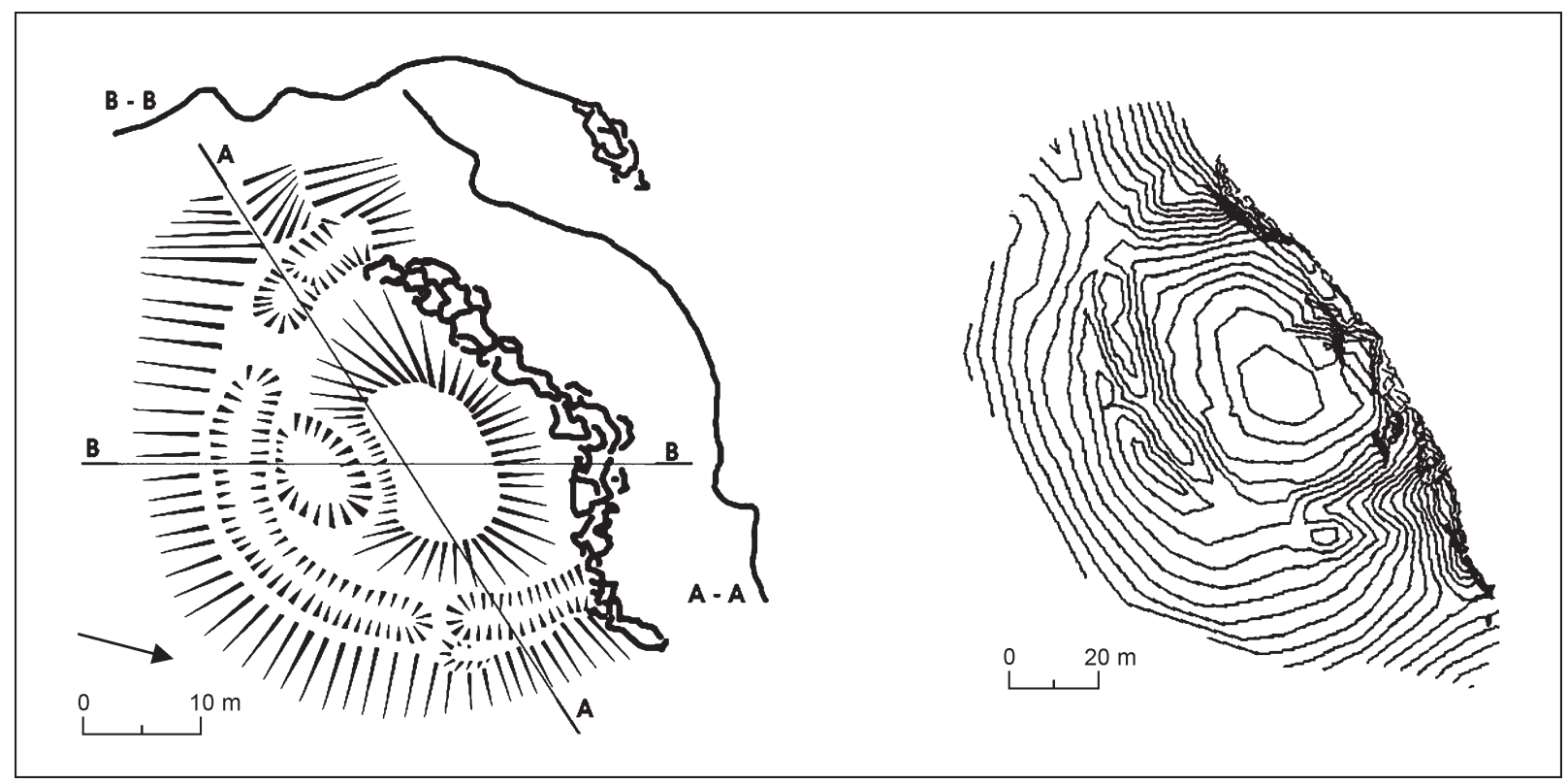

Obr. 16. Geodetické zameranie Studeného hradu. Vl’avo zameranie T. Szabóom, vpravo M. Bartíkom (@ Varak.hu http://varak.hu/Pozoruhodnosti/index/2473-Jelenec-Hidegvar [27. 3. 2017]).

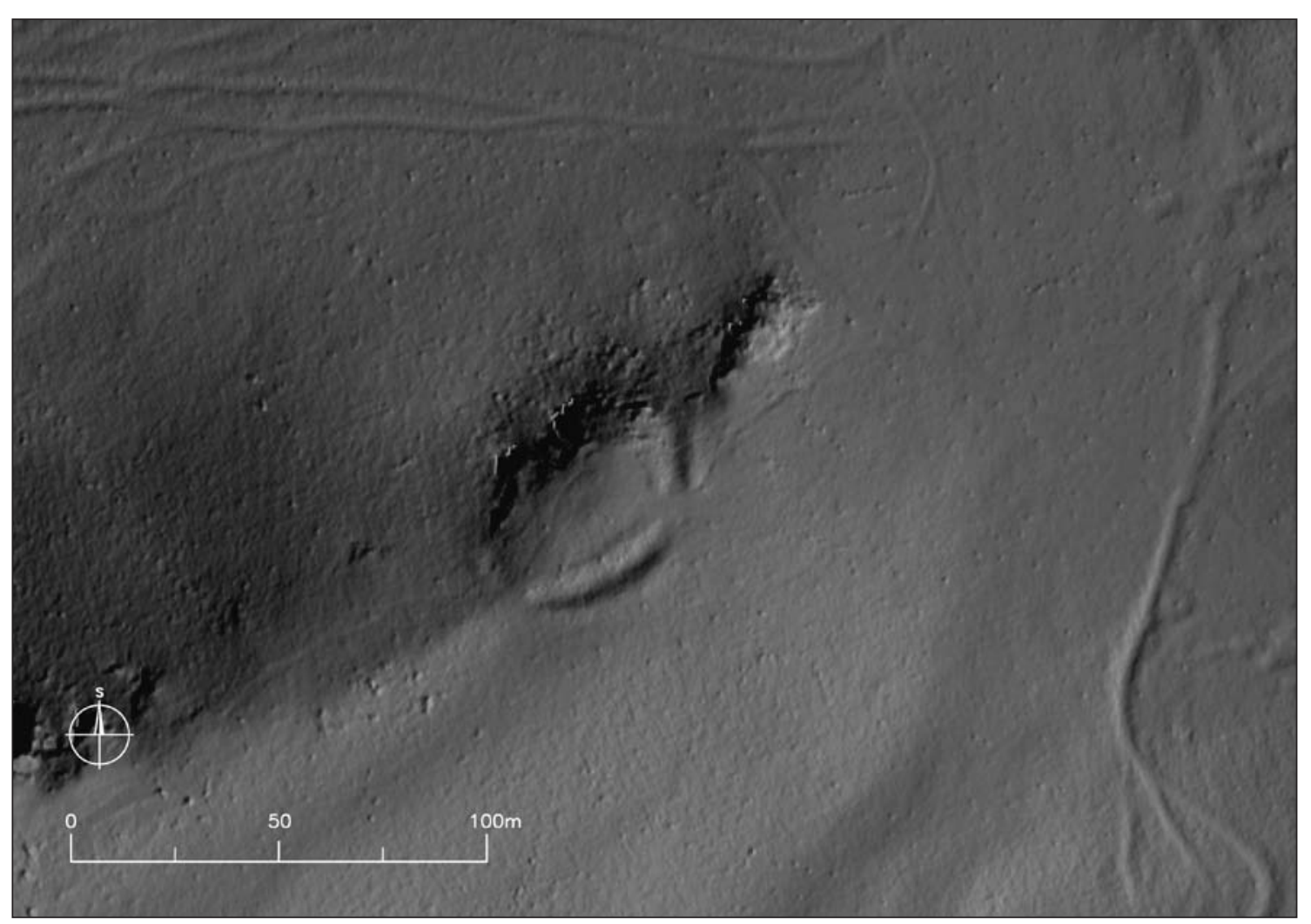

Obr. 17. Studený hrad na tieňovanom reliéfe osvetlenom z juhovýchodu (C Katedra leteckej dopravy fakulty PEDAS Žilinskej univerzity v Žiline; Geoaktuál, s. r. o.; GeoProxima, s. r. o.). 


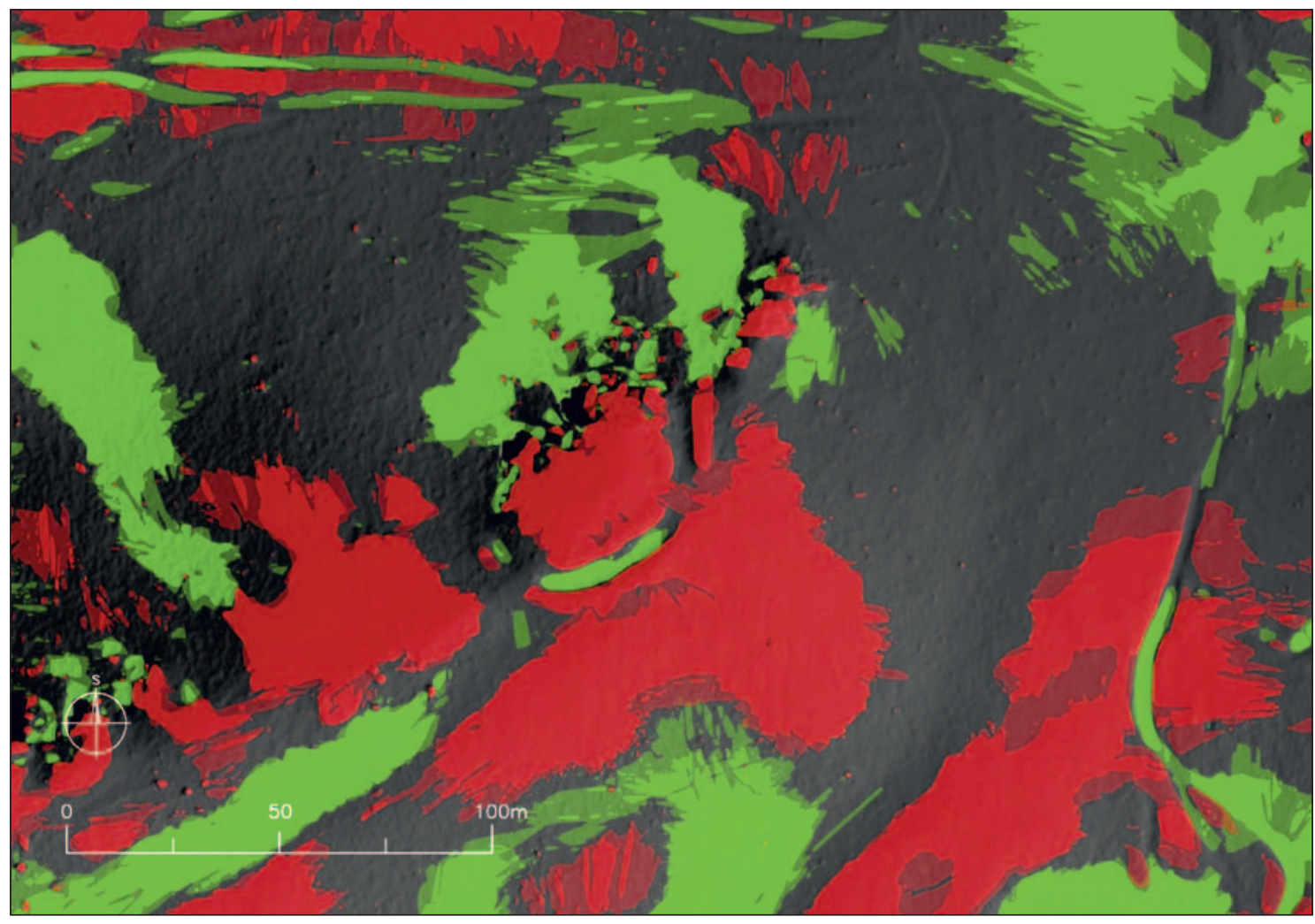

Obr. 18. Studený hrad na výstupe morfometrie konvexít (červenou farbou) a konkavít (zelenou farbou) na podklade tieňovaného reliéfu (@ Katedra leteckej dopravy fakulty PEDAS Žilinskej univerzity v Žiline; Geoaktuál, s. r. o.; GeoProxima, s. r. o.).
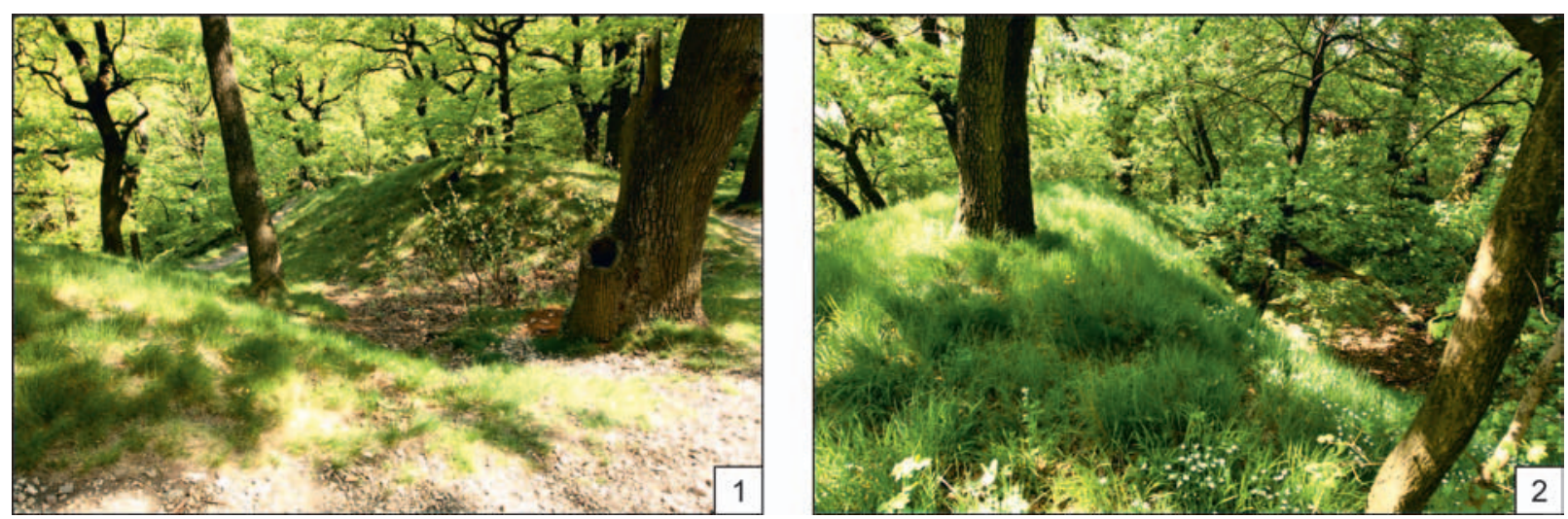

Obr. 19. Studený hrad. Priekopa a zachovalá čast’ valu, vlavo v severovýchodnej časti, vpravo vo východnej časti opevnenia. Stav z roku 2015. Foto Z. Borzová.

Zo západnej strany je plošina chránená prirodzene, skalným zrázom. Do opevnenia sa vchádzalo pravdepodobne bránou, ktorá sa nachádzala v miestach dnešného vstupu do jeho areálu, t. j. z juhovýchodnej (obr. 17; 18; Baxa/Borzová/Jahn 2016, 38). Zvyšky po objektoch v areáli opevnenia nie sú zachované. ${ }^{27}$ Obvod opevnenia je $148 \mathrm{~m}$ a vnútorná plocha opevneného sídla je 0,15 ha. ${ }^{28}$

27 Rekonštrukcia opevnenia Studeného hradu od F. Főniga je známa z internetovej stránky http://varak.hu/Pozoruhodnosti/ index/2473-Jelenec-Hidegvar [27. 3. 2017]

28 Obvod bol meraný v osi priekopy, nakol'ko os valu nie je čitatelná, taktiež vnútorná plocha bola meraná od osi priekopy (obr. 20). Tú bolo možné zrekonštruovat’ prekrytím tieňovaného reliéfu (obr. 17) a výstupu morfometrie konkavít a konvexít (obr. 18). 

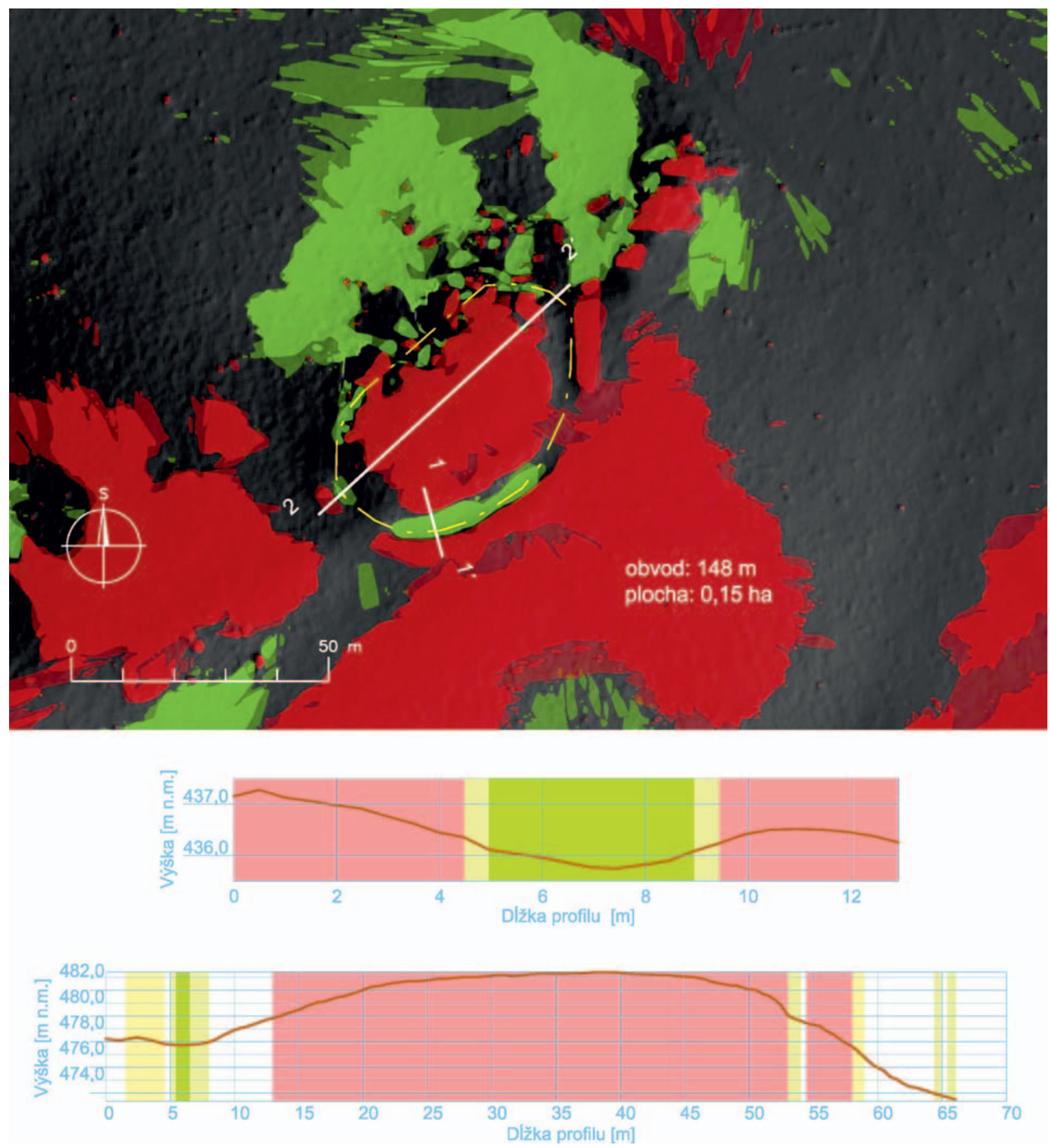

Obr. 20. Studený hrad. Geometrické údaje a priečne rezy, v ktorých je vyznačený výsledok morfometrickej analýzy konkavít a konvexít.

Datovanie ani funkcia tohto opevnenia doteraz nie je ozrejmená. Uvažuje sa o súvislosti s Gýmešským hradom, ktorému mohla táto pevnost̉ tvorit určité predsunuté opevnenie. Úvahy o staršom datovaní opevnenia zase súvisia s teóriou o „kostolianskych hradčanoch“ a ich strážnych povinnostiach v Kostolianskej kotline (Baxa/BorzoválJahn 2016, 38). Ani ojedinelý keramický materiál nájdený terénnou prospekciou nepomáha k bližšiemu datovaniu tejto lokality. Na výstupe LLS v širšom priestore horského terénu možno pozorovat’ hustú siet historických ciest, ktoré križovali túto polohu smerom zo západu na východ, ako aj z juhu na sever, teda smerom k hradu Gýmeš (obr. 21). Śtúdium týchto komunikácí́ by $\mathrm{v}$ budúcnosti mohlo napomôct' $\mathrm{k}$ zodpovedaniu otázok o funkcii a o datovaní tohto opevnenia. 


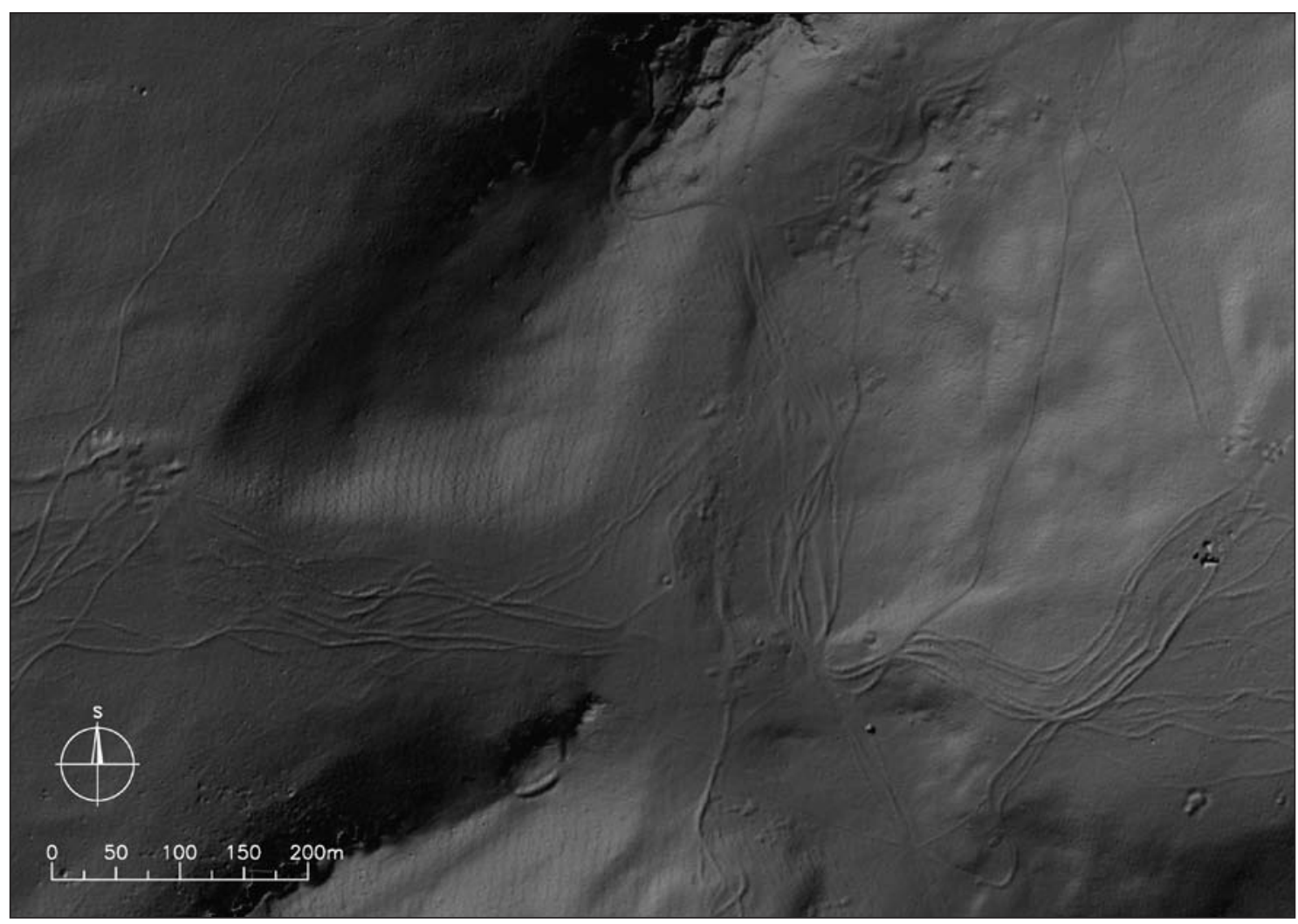

Obr. 21. Širšie okolie Studeného hradu (na juhu) a hradu Gýmeš (na severe) a splet historických ciest na tieňovanom reliéfe osvetlenom z juhovýchodu (@ Katedra leteckej dopravy fakulty PEDAS Žilinskej univerzity v Žiline; Geoaktuál, s. r. o.; GeoProxima, s. r. o.).

\section{ZÁVER}

Morfometrická analýza terénu pomocou inovatívnej metódy s využitím technológie Proxima predstavuje $\mathrm{v}$ dnešnej dobe novú metódu využitelnú aj pri nedeštruktívnom archeologickom výskume terénnych reliktov antropogénneho tvaru. $Z$ hladiska výskumu krajiny má táto metóda viacero výhod. Jednotlivé špecifiká a využitel'nost̉ tejto metódy možno demonštrovat aj na výsledkoch výskumu vybraných terénnych reliktov opevnených sídiel: hradisku Vel'ký Tribeč, stredovekom hrádku vo Velčiciach a stredovekom opevnenom sídle Studený hrad.

Metóda umožňuje lepšie identifikovat menej viditel'né terénne relikty, ako aj v detailoch sledovat tie väčšie. Ide predovšetkým o zvyšky fortifikácií, pozostatky rôznych objektov v podobe depresií alebo zvyškov architektúry, ako aj o iné komponenty, ktoré súvisia s danou lokalitou (napr. cesty alebo pramene, zdroje vody).

Pri výskume terénnych reliktov metódou Proxima je možné analyzovat’ zvlášt morfometrickú analýzu konkavít a zvlášt morfometrickú analýzu konvexít (ktoré sú definované vždy inou farbou). To umožňuje lepšie identifikovat terénne depresie a relikty, ktoré na snímkach LLS „len“ identifikujeme. Nevieme z nich však určit, či sú konkávne alebo konvexné. $Z$ tohto hladiska je metóda vel’mi účinná pri identifikácii časti opevnení, predovšetkým valov a priekop. Ako príklad možno uviest identifikáciu líniového valového útvaru, nachádzajúceho sa východne od hradiska na Vel'kom Tribeči. Podla snímok LLS nebolo možné identifikovat', či ide hlboký úvoz alebo o nejaký konvexný útvar. Prostredníctvom morfometrickej analýzy konkavít a konvexít bolo možné v tomto priestore identifikovat' val (obr. 3).

Pri sledovaní zvlášt konkavít a zvlášt konvexít možno presnejšie zachytit detailné znaky sledovaného reliktu. $\mathrm{V}$ rámci skúmaných lokalít to bolo evidentné napríklad pri detailnom skúmaní poloklieštovej brány na hradisku Velký Tribeč (obr. 4). 
Okrem vyššie uvedených výhod, táto metóda umožňuje bližšiu identifikáciu terénnych reliktov v podobe realizácie rôznych meraní ich vlastností, ako napríklad vzdialenosti medzi reliktami, ich objem, híbku a šírku priekop, výšku a šírku valu, rozmery objektu, rozsah opevnenej plochy a pod. V tomto smere možno hovorit nielen o identifikácii, ale o evidencii a detailnej dokumentácii terénnych reliktov a ich častí (obr. $5 ; 12 ; 20)$.

V neposlednom rade treba vyzdvihnút aj vizualizáciu výstupov morfometrickej analýzy, ktorá okrem dokumentačných výhod môže slúžit aj k prezentačným účelom.

Napriek všetkým vyššie zmieneným výhodám tejto metódy sa pri archeologickom výskume vybraných objektov potvrdila nutnost’ využitia ostatých/d’alších metód a následná komparácia ich výsledkov. Prejavilo sa to napríklad pri rekonštrukcii priebehu opevnenia stredovekého hrádku vo Velčiciach. Tá bola možná len prekrytím výstupov morfometrie konkavít a konvexít s tieňovaným reliéfom (obr. 10-12).

Prepojenie viacerých metód sa ukázalo ako účinné aj pri sledovaní miery deštruovania terénnych reliktov. Nové merania pomocou morfometrie konvexít a konkavít možno porovnat' s dávnejším geodetickým zameraním (alebo s inou formou dokumentácie) reliktov. Takýmto spôsobom možno rekonštruovat’ mieru rozrušenia valu alebo zanášania priekopy, teda mieru deštrukcie skúmanej lokality od poslednej dokumentácie daného reliktu.

Pri využití viacerých metód sa možno ojedinele stretnút aj s nesúladom výsledkov terénneho prieskumu a výstupov LLS a výstupoch morfometrickej analýzy konvexít a konkavít, ako to zaznamenávame v rámci interpretácie častí opevnenia na Malom Lysci (Bisták/Borzová/Borza 2017, 57).

Kostolianska kotlina a jej okolie, okrem vybraných a doposial' spracovaných terénnych reliktov antropogénneho charakteru, obsahuje ešte vel'ké množstvo ostatných reliktov, ktoré by bolo vhodné spomínanými metódami zdokumentovat a následne získané výsledky overit terénnou prospekciou. Jedným z nich sú relikty po hospodárskom využití predmetného mikroregiónu, ktoré zostávajú predmetom d’alšieho (interdisciplinárneho) výskumu.

\section{LITERATÚRA}

Baxa/Borzová/Jahn 2016

Bisták/Borzová 2013

Bisták/Borzová 2018

Bisták/Borzová/Borza 2017

Bisták/Daňo 2006

Borza 2017

Borzová 2013

Borzová 2017

Borzová et al. 2017
P. Baxa/Z. Borzová/J. Jahn: Studený hrad a horolezectvo. In: P. Baxa/Z. Borzová/P. Bisták (ed.): Sprievodca po Kostolianskom náučnom chodníku (Gýmeš-Kostolianske lúky). Bratislava 2016, 38, 39.

P. Bisták/Z. Borzová: Kostol'any pod Tribečom v praveku a včasnom stredoveku. In: P. Baxa a kol.: Kostol'any pod Tribečom. Monografia obce. Kostolany pod Tribečom 2013, 25-36.

P. Bisták/Z. Borzová: Zaniknutá skláreň vo Velčiciach (okr. Zlaté Moravce) z pohladu nedeštruktívneho archeologického výskumu. In: D. Stašíková-Štukovská (zost.): Historické sklo. Multidisciplinárne o historickom skle III. Bratislava 2018, 217-227.

P. Bisták/Z. Borzová/M. Borza: Porovnanie výsledkov terénnej prospekcie a leteckého skenovania hradiska na Vel'kom a Malom Lysci. In: Sedem decénií Petra Romsauera. Studia Historica Nitriensia. Supplementum. Mimoriadne číslo časopisu venované životnému jubileu prof. Petra Romsauera. Nitra 2017, 49-60.

P. Bisták/R. Daňo: Kostol’any pod Tribečom. Výskumná správa. Dokumentácia KPÚ Nitra. Nitra 2006. Nepublikované.

M. Borza: Vyhodnotenie LIDARových dát v Kostolianskej kotline a jej širšom okolí. Nitra 2017. Nepublikované.

Z. Borzová: Ladice vo svetle archeologických prameňov. In: Z. Borzová a kol.: Ladice v premenách času. Ladice 2013, 21-30.

Z. Borzová: Kostolianska kotlina v premenách času. Stav a perspektívy archeologického a interdisciplinárneho výskumu krajiny. Habilitačná práca (Katedra archeológie UKF v Nitre) Nitra 2017. Nepublikované.

Z. Borzová/P. Bisták/M. Borza/A. Smetanová: Relikty hospodárskeho využitia krajiny v Kostolianskej kotline (masív Vel'kého Lysca a Ploskej) z pohladu leteckého laserového skenovania. In: M. Hajnalová/N. Beljak Pažinová/ K. Šimunková (ed.): Človek a krajina... Integrácia paleoenvironmentálneho 
Borzová/Borza/Bisták 2014

Borzová/Čurný/Pažinová 2010

Borzová/Pažinová 2009

Bóna 2011

Habovštiak 1964

Habovštiak 1968

Habovštiak 1985

Holubec et al. 2016

Ihring/Hronček/Holobec 2014

Jahn 1997

Jahn 2009

Janšák 1929

Jaššo 2007

Jaššo 2009

Katkinová/Katkin 2002

Mitáš/Žáčik 2011

Porubský 1956

Ruttkay 2004

Ruttkay 2015

Ruttkayová/Ruttkay 1991

Ruttkayová/Ruttkay 2015

Samuel/Jahn/Hunka 2003

Szabová/Hronček 2015

Tirpák 2003

Veliačik/Romsauer 1994 a archeologického záznamu, adaptácie človeka na zmeny krajiny a odolnost’ krajiny na l’udský impakt. Kniha abstraktov 13. Konferencia environmentálnej archeológie. 6.-7. február 2017. Nitra 2017, 19.

Z. Borzová/M. Borza/P. Bisták: Interdisiplinárny výskum Kostolianskej kotliny - stav a perspektívy. In: A. Hořínková/P. Kováčik/S. Stuchlík (ed.): Archeologický výzkum krajiny a aplikace ICT. Opava 2014, 17-53.

Z. Borzová/M. Čurný/N. Pažinová: Nové poznatky o stredovekom a novovekom osídlení Horných Lefantoviec a Kostolian pod Tribečom. Študijné zvesti AÚ SAV 47, 2010, 5-24.

Z. Borzová/N Pažinová: Osídlenie Kostolianskej doliny. Monumentorum tutela 21, 2009, 29-44.

M. Bóna: Hrad Gýmeš. Stručný sprievodca po zrúcanine hradu. Bratislava 2011.

A. Habovštiak: Velčice, hrádok. Nálezová správa 2162/64. Dokumentácia AÚ SAV. Nitra 1964. Nepublikované.

A. Habovštiak: Archeologický výskum v Kostol'anoch pod Tribečom. Monumentorum tutela 2, 1968, 43-77.

A. Habovštiak: Stredoveká dedina na Slovensku. Bratislava 1985.

M. Holubec/P. Bobál/S. Hronček/F. Birošík: Využitie leteckého laserového skenovania pre potreby archeologického prieskumu. In: GIS Ostrava 2016. Ostrava 2016, 1-3.

P. Ihring/S. Hronček/M. Holubec: Možnosti využitia diferenciálnej geometrie pre analýzu digitálnych geografických dát. Aero-Journal 2, 2014, 48-54.

J. Jahn: Zabudnutá huta pri Velčiciach. Krásy Slovenska 74, 1997, 9, 10.

J. Jahn: Geotopy kameňolomov Tribeča. Nitra 2009.

Š. Janšák: Slovenské hradiská z doby halštatskej. In: Sborník muzeálnej slovenskej spoločnosti 23. Turčiansky sv. Martin 1929, 1-32.

F. Jaššo: Stredoveké hrádky na západnom Slovensku. Musaica 25, 123-140.

F. Jaššo: Stredoveké opevnené sídla nižšej šlachty na západnom Slovensku. Dizertačná práca (Katedra archeológie Univerzity Komenského v Bratislave). Bratislava 2009. Nepublikované.

J. Katkinová/S. Katkin: Prieskum hradiska Vel'ký Tribeč. AVANS 2001, 2002, 83,84 .

V. Mitáš/M. Žáčik: Archeologické nálezy z Kovariec. AVANS 2008, 2011, 195. J. Porubský: Jelenec, poloha Studený hrad. Nálezová správa 448/56 a 731/56. Dokumentácia AÚ SAV. Nitra 1956. Nepublikované.

M. Ruttkay: Prieskum a dokumentácia stredovekých opevnení v pohorí Tríbeč. AVANS 2003, 2004, 160.

M. Ruttkay: Využitie leteckej prospekcie a skenovania pri výskume hradísk a ich zázemia na západnom Slovensku. In: K. Pieta/Z. Robak (ed.): Bojná 2. Nové výsledky výskumov včasnostredovekých hradísk. Nitra 2015, 297-333.

J. Ruttkayová/M. Ruttkay: Archeologické nálezy v zbierkach Zlatomoraveckého múzea v Zlatých Moravciach. Nitra 1991.

J. Ruttkayová/M. Ruttkay: Horné Požitavie. Svedectvo archeológie. Nitra 2015.

M. Samuel/J. Jahn/J. Hunka: Prieskum zaniknutých hút v pohorí Tribeč. AVANS 2002, 2003, 124, 125.

M. Szabova/S. Hronček: Investigating geohazards. Lidar Reveals the Turbulent Life of Mountain Slopes. LIDAR Magazine 5/6, 2015, 48-52.

J. Tirpák: Geofyzikálny prieskum - Velčice, poloha Vel’ká paráda. Nálezová správa 15071/03. Dokumentácia AÚ SAV. Nitra 2003. Nepublikované.

L. Veliačik/P. Romsauer: Vývoj a vzt’ah osídlenia lužických a stredodunajských popolnicových polí na západnom Slovensku. Katalóg. Nitra 1994.

Internetový zdroj:

http://varak.hu/Pozoruhodnosti/index/2473-Jelenec-Hidegvar [27. 3. 2017] 


\title{
Documentation of Terrain Relics of Fortified Settlements in the Kostolianska kotlina Basin and its Wider Surroundings by Means of Modern Methods
}

\author{
Zuzana Borzová - Martin Borza
}

\author{
Summary
}

As for spatial distribution of archaeological sites, the Kostolianska kotlina basin with its wider surroundings is an area which is typical for frequent occurrence of terrain relics of anthropogenic character from various historical epochs

Investigation of terrain relics requires - apart from interdisciplinary cooperation and use of results from other fields of study - application of multiple archaeological methods and further comparison of obtained results. The aim of this article is to point not only to the above mentioned fact but mainly to possible use of new (non-destructive) methods for identification, documentation and recording as well as further research of selected terrain relics of historical fortified settlements in the Kostolianska kotlina basin and its surroundings. It is a prehistoric hillfort of Vel'ký Tribeč and relics of medieval fortified settlements - the hillfort in Velčice and the fortified settlement of Studený hrad.

A digital model has been created using aerial archaeology, the method of remote sensing landscape survey. By means of aerial laser scanning (ALS) in 2015, it was possible to observe and closely investigate the above mentioned relics of historical fortifications on the outputs of shaded reliefs. Morphometric analysis of terrain by means of an innovative method using the Proxima technology was used to simplify automatic identification and analysis of structural elements of digital terrain model related to the above mentioned archaeological sites. This method offers a different view of the terrain. Unlike global visual evaluation of digital relief model by means of illuminating it from various directions, this analysis shows local convexities and concavities of the terrain regardless of the observation direction. From the aspect of landscape survey, this method has several advantages.

This method allows better identification of less visible terrain relics and observe the larger ones in detail. These are mainly remains of fortifications (Fig. 3; 11; 18), remains of various features in form of depressions or remains of architecture (Fig. 11) as well as other components associated with the given site (e. g. roads or springs - water sources; Fig. 11).

When investigating terrain relics by means of Proxima method, it is possible to analyze morphometric analysis of concavities and morphematic analysis of convexities (which are defined by a different colour each time) separately. This allows better identification of terrain depressions and relics which are only identified on ALS photos but not determined as concave or convex. From this point of view, the method is very effective for identification of parts of fortification, mainly ramparts and ditches. We can mention identification of a line-shaped rampart as an example; it is situated east of the hillfort of Vel'ký Tribeč. ALS photos did not show whether it was a deep hollow or a convex shape. By means of morphometric analysis of concavities and convexities, it was possible to identify a rampart in this area (Fig. 3).

When observing concavities and convexities separately, we can detect detailed features of the studied relic more precisely. It was apparent e. g. in the detailed investigation of the semi-tongs gate at the hillfort of Vel'ký Tribeč (Fig. 4).

Besides the above mentioned advantages, this method allows closer identification of terrain relics by executing various measurings of their qualities, such as distance between the relics, their volume, depth and width of the ditches, height and width of the rampart, size of the feature, size of the fortified area, etc. Thus, we can speak of not only identification but also recording and detailed documentation of terrain relics and their parts (Fig. 5; 12; 20).

The last but not least, we must mention the visualisation aspect of the morphometric analysis outputs which can be used for documentation as well as presentation purposes.

In spite of all the above mentioned advantages of this method, the archaeological investigation of selected features confirmed the necessity of use of other methods and further comparison of their results. It occurred for instance at reconstruction of the fortification of the medieval hillfort in Velčice. This was possible only by superimposing outputs of morphometry of concavities and convexities over the shaded relief (Fig. 10-12).

Interconnection of multiple methods proved effective also when monitoring the extent of destruction of terrain relics. New measurings by means of morphometry of convexities and concavities can be compared with older geodetic measuring (or another form of documenting) of relics. Thus, we can reconstruct the extent of the rampart's destruction or backfill of the ditch, i. e. the extent of destruction of the studied site since the last documentation of the given relic.

When using multiple methods, we can occassionally come across a discrepancy between the results of terrain surveys and ALS outputs and outputs of the morphometric analysis of convexities and concavities, as documented within interpretation of part of the fortification at Malý Lysec (Bisták/Borzová/Borza 2017, 57).

The Kostolianska kotlina basin and its surroundings contains - besides the selected and previously processed terrain relics of anthropogenic character - a large amount of other relics which should be documented by means of the above mentioned methods and the obtained results should be later verified by terrain prospecting. We could mention relics of economic use of the studied microregion which remain subject to further (interdisciplinary) investigation. 
Fig. 1. Vel'ký Tribeč, hillfort plan from 1929 (according to Janšák 1929, fig. 24).

Fig. 2. Vel'ký Tribeč on the shaded relief under northeastern illumination (@ Department of Air Transport of Faculty of Operation and Economics of Transport and Communications at the University of Žilina; Geoaktuál, s. r. o.; GeoProxima, s. r. o.).

Fig. 3. Vel'ký Tribeč on the output of morphometry of convexities (red) and concavities (green) on the background of the shaded relief (@ Department of Air Transport of Faculty of Operation and Economics of Transport and Communications at the University of Žilina; Geoaktuál, s. r. o.; GeoProxima, s. r. o.). Legend: a - gate in the northwestern part of the hillfort; $b$ - gap in the rampart in the western part of the fortification; $c$ - anomaly in form of a convexity; $d$ - gap in the rampart in the southwestern part; e - gap in the rampart in the southern part; $\mathrm{f}$ - gap in the rampart in the southeastern part; $\mathrm{g}$ - gap in the rampart in the northeastern part; $\mathrm{h}$ - line fortification.

Fig. 4. Vel'ký Tribeč. Detailed view of the northwestern and northeastern gates on the output of morphometry of convexities (red) on the background of the shaded relief (@) Department of Air Transport of Faculty of Operation and Economics of Transport and Communications at the University of Žilina; Geoaktuál, s. r. o.; GeoProxima, s. r. o.).

Fig. 5. Vel'ký Tribeč. Geometric data of the hillfort and cross-sections with indicated result of the morphometric analysis of concavities and convexities.

Fig. 6. Vel'ký Tribeč. Remains of the rampart fortification at the hillfort. Situation in 2004. Photo by P. Bisták.

Fig. 7. Vel'ký Tribeč. Rampart fortification of the hillfort interrupted by a new forest trail. The rampart is much taller in these points than in cross-sections (Fig. 5). Situation in 2004. Photo by P. Bisták.

Fig. 8. Vel'ký Tribeč. Enclosure wall of a dry-stoned feature at the hillfort. Situation in 2004. Photo by P. Bisták.

Fig. 9. Fortified settlement in Velčice. Measuring according to A. Habovštiak (1985, 321).

Fig. 10. Fortified settlement in Velčice on the shaded relief illuminated from the north (@ Department of Air Transport of Faculty of Operation and Economics of Transport and Communications at the University of Žilina; Geoaktuál, s. r. o.; GeoProxima, s. r. o.).

Fig. 11. Fortified settlement in Velčice on the output of the morphometry of convexities (red) and concavities (green) on the background of the shaded relief (C Department of Air Transport of Faculty of Operation and Economics of Transport and Communications at the University of Žilina; Geoaktuál, s. r. o.; GeoProxima, s. r. o.). Legend: a - gap in the rampart in the northern part; b - gap in the rampart in the southern part; $\mathrm{c}$ - traces of a tower-shaped structure; $\mathrm{d}$ - terrain depressions in the area of fortification; $\mathrm{e}$ - artificial dam on the stream; $\mathrm{f}$ - cistern.

Fig. 12. Fortified settlement in Velčice - geometric data and cross-sections with indicated result of the morphometric analysis of concavities and convexities.

Fig. 13. Course of the ditch in the northern part of the area of the medieval hillfort in Velčice, situation in 2014. Photo by P. Bisták.

Fig. 14. Remains of a tower-shaped structure - disturbed wall coping of the tower of the medieval hillfort in Velčice. Situation in 2014. Photo by P. Bisták.

Fig. 15. Fortified settlement in Velčice - elevation with remains of a masonry tower, situation in 2014. Photo by P. Bisták.

Fig. 16. Geodetic measuring of Studený hrad. Left by T. Szabó, right by M. Bartík (@) Varak.hu http://varak.hu/Pozoruhodnosti/index/2473-Jelenec-Hidegvar [27. 3. 2017]).

Fig. 17. Studený hrad on the shaded relief illuminated from the southeast (@ Department of Air Transport of Faculty of Operation and Economics of Transport and Communications at the University of Žilina; Geoaktuál, s. r. o.; GeoProxima, s. r. o.).

Fig. 18. Studený hrad on the output of the morphometry of convexities (red) and concavities (green) on the background of the shaded relief (@ Department of Air Transport of Faculty of Operation and Economics of Transport and Communications at the University of Žilina; Geoaktuál, s. r. o.; GeoProxima, s. r. o.).

Fig. 19. Ditch and the preserved part of the rampart, left of the norhteastern part, right of the eastern part of the Studený hrad's fortification. Situation in 2015. Photo by Z. Borzová.

Fig. 20. Studený hrad. Geometric data and cross-sections with indicated result of the morphometric analysis of concavities and convexities.

Fig. 21. Wider surroundings of Studený hrad (in the south) and the Gýmeš castle (in the north) and the network of historical trails on the shaded relief illuminated from the southeast (C Department of Air Transport of Faculty of Operation and Economics of Transport and Communications at the University of Žilina; Geoaktuál, s. r. o.; GeoProxima, s. r. o.).

doc. Mgr. Zuzana Borzová, PhD.

Katedra archeológie

UKF v Nitre

Hodžova 1

SK - 94974 Nitra

zborzova@ukf.sk
Ing. Martin Borza

Geoaktuál, s. r. o.

Bernolákova 13

SK - 92509 Šal’a

mborza@geoaktual.sk 